Summer 8-24-2020

\title{
Improving Patient Satisfaction in the Medical-Surgical Setting
}

Victoria A. Ogundeko

University of St. Augustine for Health Sciences, v.ogundeko@usa.edu

DOI: https://doi.org/10.46409/sr.KZFE9388

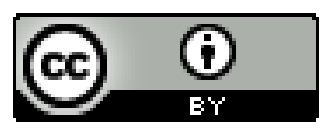

This work is licensed under a Creative Commons Attribution 4.0 License.

Follow this and additional works at: https://soar.usa.edu/scholprojects

Part of the Nursing Administration Commons

\section{Recommended Citation}

Ogundeko, V. A. (2020). Improving Patient Satisfaction in the Medical-Surgical Setting. [Doctoral project, University of St Augustine for Health Sciences]. SOAR @ USA: Student Scholarly Projects Collection. https://doi.org/10.46409/sr.KZFE9388

This Scholarly Project is brought to you for free and open access by the Student Research at SOAR @ USA. It has been accepted for inclusion in Student Scholarly Projects by an authorized administrator of SOAR @ USA. For more information, please contact soar@usa.edu, erobinson@usa.edu. 


\title{
Improving Patient Satisfaction in the Medical-Surgical Setting
}

\author{
Victoria A. Ogundeko, MSN, RN, CNS, PHN \\ School of Nursing, University of St. Augustine for Health Sciences \\ This Manuscript Partially Fulfills the Requirements for the \\ Doctor of Nursing Practice Program and is Approved by: \\ Douglas M. Turner, Ph.D., DNP, RN, CNE, NE-BC, NEA-BC \\ EM Vitug Garcia, Ph.D., DHEd, DNP, MSN-PCNP/Ned, MBA, MAEd, APRN, NP-C, CNOR, \\ CSSM, FACLNC, FIAAN
}

September 10, 2020 
University of St. Augustine for Health

Sciences DNP Scholarly Project

Signature Form

\begin{tabular}{|l|l|l|}
\hline $\begin{array}{l}\text { Student Last Name: } \\
\text { Ogundeko }\end{array}$ & First Name: & $\begin{array}{l}\text { Middle } \\
\text { Initial: } \\
\text { A }\end{array}$ \\
\hline
\end{tabular}

E-mail:

v.ogundeko@usa.edu

Title of DNP Project:

In hospitalized medical-surgical patients, does the implementation of nursing bedside handoff report compared to the current desk handoff report improve patient satisfaction scores by $10 \%$ in two months?

I have reviewed and approved this final written DNP Project. My typed name below serves as my electronic signature.

\begin{tabular}{|c|r|r|l|}
\hline Faculty/Preceptor Typed Name & $\begin{array}{l}\text { Electronic } \\
\text { Signature }\end{array}$ & Email Address & Date \\
\hline $\begin{array}{l}\text { DNP Project Primary Faculty: } \\
\text { Douglas M Turner }\end{array}$ & & & \\
\hline $\begin{array}{l}\text { DNP Project Preceptor: } \\
\text { EM V. Garcia, PhD, DNP, APRN, NP-C }\end{array}$ & emgarcia@primehealthcare.com & $08 / 21 / 20$ \\
\hline DNP Project Preceptor: & & & \\
\hline
\end{tabular}




\begin{abstract}
Practice Problem: Patients' experiences at hospitals are multidimensional, and their satisfaction with the service is linked to the quality of patient care provided. In evaluating the quality of care of a hospital, the nursing handoff of patients, and the engagement efforts of healthcare staff is an important element of patient satisfaction.
\end{abstract}

PICOT: In adult medical-surgical patients, does the implementation of nursing bedside handoff reports, compared to the current method of nursing practice desk handoff reports, improve patient satisfaction scores by $10 \%$ within two months?

Evidence: After reviewing 103 articles, 12 were relevant to this project, and included observation of an acute care setting and a focus on patient satisfaction.

Intervention: The patients' satisfaction and experience in the medical-surgical unit were measured by assessing the pretest and posttest evaluations with the Bradley inpatient (I-PAHC) and outpatient (O-PAHC) questionnaire.

Outcome: The results of the paired sample $t$-test revealed that patients' satisfaction levels with nurses $(t(25)=-4.606, p<.05)$ and satisfaction levels with physicians $(t(25)=-6.024, p<.05)$, both significantly improved after the intervention. In a regression model examining the relationship between the postintervention measure of nurse satisfaction and the overall hospital rating score, no clinical significance was noted between the two variables $\left(R^{2}=0.128, F(1,24)\right.$ $=3.538, p>.05)$.

Conclusion: The project illuminated the need to continue educating nurses bi-annually to sustain the hospital's practice change and improve patient satisfaction. Time for more interprofessional collaboration should be provided for staff to be able to balance their time between bedside care and other tasks to learn evidence-based techniques related to patient satisfaction. 


\section{Improving Patient Satisfaction in the Medical-Surgical Setting}

Factors that influence patients' experience at the hospital, and the satisfaction of the care they received is multifaceted (Berkowitz, 2016). Stricter reimbursement and performance guidelines are normal standards in healthcare, and many organizations use patient satisfaction as a metric of the healthcare payment system for quality care (Berkowitz, 2016; Xesfingi \& Vozikis, 2016). Information related to patient satisfaction includes the ability of the care providers to meet patients' expectations, along with patients' perspectives and behavioral intentions (Xesfingi \& Vozikis, 2016). Furthermore, the measure of patient satisfaction can help guide clinical outcomes and improve patient loyalty.

The practice of nursing handoff at hospitals affects patient satisfaction. Bedside handoffs involve the transition of responsibility from one nurse to another regarding a patient's care (Ford \& Heyman, 2017). In 2006, The Joint Commission recognized that standardized nursing handoff communication is one of the National Patient Safety Goals (Berkowitz, 2016). The primary rationale for nurses to conduct an end of shift handoff at the patient's bedside is to encourage the patient and family to play a part in the process (Berkowitz, 2016). A patient's satisfaction and participation in the service enhances their feelings of safety, and patient satisfaction is linked to the frequency of bedside handoffs (Ford \& Heyman, 2017). The purpose of this evidence-based project was to find out if the implementation of nursing bedside handoff reports, instead of the current practice of the desk handoff reports, would improve patient satisfaction scores in a medical-surgical unit by $10 \%$ within two months as measured by the HCAHPS score. 


\section{Significance of the Practice Problem}

Bedside nursing handoffs are used to improve patient care quality, healthcare outcomes, and patient satisfaction (Jones, 2016). The miscommunication between healthcare providers during handoff processes can significantly impact patient satisfaction (The Joint Commission, 2018). Goncalves et al. emphasized that critical information is often lost during the handoff process, which affects the delivery of care to patients (2016). The transfer of a patient from one nurse to another increases the possibility of miscommunication (Hughes, 2012).

Miscommunication increases the risk of medication errors and complications, lengthens the hospital stay, and increases treatment (Ahmed et al., 2019).

A community hospital at Los Angeles struggles with patient experience and satisfaction scores based on inpatient surveys after discharge, as shown in the Healthcare News and Healthgrades websites. Patient satisfaction scores and communication with health providers were low in the community hospital, ranking between one or two out of five stars (Healthcare News, 2020). The hospital ranking method in California is called Healthgrades ratings, and it showed that $61 \%$ of patients ranked their satisfaction of their care at the hospital $8 \%$ lower than the national average. The goal of the medical-surgical unit was to increase its patient satisfaction scores by $10 \%$ over a period of two months.

\section{Patient/Family}

Increased competition in the healthcare field has influenced patients' experiences with hospital care (Karaca \& Durna, 2019). It is crucial to improve patients' expectations, hospital experience, and satisfaction to maintain high hospital rankings. Patients' and families' perception of the care received is a direct measurement of the hospital's quality of nursing care (Goh et al., 2016). Individuals who are not accurately diagnosed or cared for appropriately will quickly 
change healthcare facilities (Karaca \& Durna, 2019). In contrast, patients who contribute to their plan of care and interact well with their nurses and healthcare providers express satisfaction, which results in greater adherence to recommended treatment plans and more positive health outcomes (Karaca \& Durna, 2019). Bedside handoffs can help patients and nurses to have better healthcare outcomes.

\section{Healthcare System}

Patient satisfaction is a vital measurement of healthcare quality because it assesses the success of healthcare providers in meeting their patients' needs and expectations (Xesfingi \& Vozikis, 2016). Furthermore, patient satisfaction is also a significant factor in determining a patient's perception and compliance with healthcare recommendations (Xesfingi \& Vozikis, 2016). In the healthcare system, increased patient satisfaction is linked to compliance, diminished use of medical services, decreased malpractice and litigation, and positive healthcare outcomes (Xesfingi \& Vozikis, 2016). In the last decade, patient satisfaction has been measured by surveys that focus on the patient's experience and quality of care, including waiting time, hospital cleanliness, and communication with healthcare providers (Patwardhan \& Spencer, 2012). Patwardhan and Spencer (2012) emphasized that evidence-based projects from the patient's perspective is connected to the safety, availability, equity, and inclusiveness of care. From a provider's perspective, higher patient satisfaction increases customer retention and increase revenue (Patwardhan \& Spencer, 2012).

\section{Global Patient Satisfaction Incidence and Prevalence}

Customer satisfaction plays an essential role in the quality of healthcare and service delivery reforms (Bleich, 2009). However, the results of satisfaction studies are limited due to the lack of universal acceptance of the definition of customer satisfaction or consistent 
implementation of satisfaction standards (Bleich, 2009). Several organizations and researchers have focused on patient satisfaction related to the quality and health service provided, while others have concentrated on the healthcare system (Bleich, 2009). Both perspectives are imperative in evaluating patient satisfaction because content and comfortable individuals are more compliant with treatments, health services, and medication regimens. Patients who are pleased with their hospital care experience report better health outcomes and lower service costs.

\section{Framework of the Problem}

Kurt Lewin's (1951) Change Model, which consists of three stages — unfreeze (change), freeze, and refreeze — served as the framework and foundation for this evidence-based project. This model provided a simple and practical approach for comprehending the bedside nursing handoff change process in a personal and organized method (Lewin, 1951). For this evidencebased project, the unfreezing stage involved encouraging and preparing the nursing staff for the change in how bedside handoff reports were conducted. Next, the freezing stage involved motivating the team to accept and implement the change. Finally, the refreezing phase entailed new behavior patterns for the nursing staff to continue performing bedside handoff reports.

\section{Unfreezing}

The goal in this phase was to prepare the nursing staff to accept change. This step involved identifying the needed changes, which involved conducting bedside handoff reports. The hospital's website and HCAHPS report regarding patient satisfaction showed that change was required to increase the scores because the hospital's benchmark was below national compliance rates. To prepare the nursing staff for the additional responsibility, an intercollaboration team formed, which discussed buy-in with the nursing management team. Lewin's 
(1951) change theory emphasizes that changes must be presented slowly to the staff, and the need for change must be established for success with any change.

\section{Freezing}

In this phase, the promotion and execution of bedside handoff reporting occurred. During this step, the nursing staff and the management team met weekly. Stakeholders were kept abreast of the project during bi-monthly meetings, ensuring that all participants remained aware of the project's goals and objectives. Furthermore, the nursing staff received education and training sessions during this phase. Ultimately, the goal of the training was to foster transparent communication among all involved individuals to obtain greater buy-in.

\section{Refreezing}

This last stage begins when evidence-based change is executed and becomes an organization's standard of practice (Lewin, 1951). During this phase, the nursing staff began to integrate organizational culture into their work, hence resisting further change (Lewin, 1951).

During this stage, risk factors that hinder changes and implementation of strategies are identified (Lewin, 1951).

\section{Scholarly Question}

The PICOT question for this project was: In adult medical-surgical patients, does the implementation of nursing bedside handoff reports, compared to the current method of nursing practice desk handoff reports, improve patient satisfaction scores by $10 \%$ within two months? $\mathrm{P}$ - Adult hospitalized medical-surgical patients

I - Bedside handoff report education $\mathrm{C}$ - Compared to current nursing practice desk handoff $\mathrm{O}-$ Nursing adherence that increases patient satisfaction scores by $10 \%$ 
T - Two months

\section{Population}

The targeted population for this project was hospitalized medical-surgical patients between the ages of 18 to 65 years. The exclusion criteria included patients younger than 18 years of age, those unable to read or write English, and individuals with neurological or mental deficiencies, or altered mental status due to medication. The project included a comparison of the patient's orientation status against a previous nursing assessment. If visitors were present, permission was sought from the patient to have them included in the hand-off. All individuals were well informed of the project's purpose, risks, benefits, and confidentiality procedures.

\section{Intervention}

The intervention of this project began with a pre-evaluation of the hospital's HCAHPS scores related to patient satisfaction and beside handoff reports. A month before implementing the project, an interprofessional team formed, which included a nurse manager, unit secretary, certified nursing assistant, nurse liaison, and two registered nurses (day and night). The input was obtained from all members of the team during the project's planning and implementation phase.

The intervention used for the project was the implementation of the bedside handoff report, which incorporated the patient's input. For the intervention, a pretest was given to the patients regarding patient satisfaction. The nursing staff was provided an interactive educational intervention regarding patient satisfaction and the hospital's HCAHPS scores for the past year. Each patient completed a pre-patient satisfaction test upon admission and a satisfaction posttest on the day of their discharge. The pretest and posttest scores showed a difference between the previous nursing practices (none) eight weeks after the intervention was completed. 


\section{Comparison}

Before the launch of this project, the comparison intervention was the annual report retrieved from the HCAPHS, Healthcare News, the hospital website, and the clinical nurse manager's information. The information on the hospital website was based on the surveys received from the hospital's inpatients after their discharge. The information included ten categories, which were further categorized into six reasons for patient experience/satisfaction results. Below are the scores from the HCAPHS:

1. Satisfaction with the hospital: $2 / 5(40 \%)$

2. Willingness to recommend: $2 / 5(40 \%)$

3. Satisfaction with MD communication: 2/5 (40\%)

4. Satisfaction with nurses' communication: 2/5 (40\%)

5. Satisfaction with discharge information: 1/5 (20\%)

6. Staff responsiveness: $2 / 5(40 \%)$

The national benchmarks for patient satisfaction are as follows: nursing communication $80 \%$, discharge instructions $53 \%$, explanation of medications at $66 \%$, and physician communication at $82 \%$ (Data.Medicare.gov, 2018). The identified gap was noted in the nursing communication related to discharge instructions, explanation of medications, and procedures.

\section{Outcome}

The intended outcome was for the medical-surgical nursing staff to use better communication skills to foster stronger connections with their patients. An evaluation and comparison of the pre-implementation rates and the post-implementation rates showed an increase in satisfaction. Two goals were set in place: the first goal was for medical-surgical patients to report higher nursing communication related to discharge instructions, medications, 
and procedures, and the second goal was for the hospital ratings to increase by one star from its initial standing (i.e., $3 / 5$, or $60 \%$ ).

\section{Time}

The proposed timeline for this evidence-based project was eight weeks. However, due to the COVID-19 pandemic, data was collected and evaluated later than anticipated. The management of the hospital developed new policies for conducting projects to abide by the latest Centers for Disease and Prevention Control (CDC) and state guidelines regarding the disease. Weekly project updates occurred through the hospital's email system and Zoom platforms.

The goal of the project was to increase the nursing staff's awareness and decision-making processes related to bedside handoff reporting while also improving patient satisfaction scores. The clinical question was: In adult medical-surgical patients, does the implementation of nursing bedside handoff reports, compared to the current method of nursing practice desk handoff reports, improve patient satisfaction scores by $10 \%$ within two months?

The justification for the $10 \%$ benchmark was twofold. First, a $50 \%$ increase in patient satisfaction scores could not be achieved due to the timeframe limitation of the project because of the pandemic. Second, there was a possibility that incremental improvement would effectively motivate the staff to continue reaching higher benchmarks throughout the year.

\section{Literature Search Strategy}

This evidence-based project included searches from the following databases for the literature review: CINAHL, Cochrane Database of Systemic Reviews, ProQuest, PubMed, Medline, and Google Scholar. The selected studies were full-text, English-written journals published in the past five years, to offer the most relevant and current evidence-based information to discuss the PICOT question. Some older articles were relevant and included in the project. The inclusion 
criteria consisted of systematic and peer-reviewed articles, evidence-based research, and studies based on patient satisfaction and bedside handoff reports. The selected journals contained information related to answering the PICOT question.

\section{Exclusion Criteria}

The literature review for this project did not include articles that did not focus on communication, education intervention or patient satisfaction, or articles published in a language other than English. Additionally, any literature that did not contain specific keywords related to the project and failed to meet the scholarly standards were excluded, along with articles published before the year 2015. Other excluded literature during the research process of this project included abstract-only articles, wrong interventions, and articles based on expert opinions.

\section{Literature Search Results and Evaluation}

The search produced a total of 2,468 articles. The most relevant evidence was identified by applying inclusion and exclusion criteria to guide and focus the project. After a literature scan throughout the different databases, critical appraisals assisted in the evaluation of the clinical and statistical relevance of the selected articles. Most articles revealed expert opinions. Exclusion criteria was applied to abstracts and title screening, which resulted in 103 articles. After reviewing the 103 articles, a dozen met the standards for relevance to the project. Articles excluded in the elimination process of this review included literature reviews, articles that focused on other forms of hand-offs or occurred in a long-term care setting. Articles included were those that took place in an acute care setting and focused on patient satisfaction. The 12 articles were then organized, analyzed, and summarized to provide more information about the 
PICOT question. The search process is summarized in the PRISMA model diagram illustrated in Figure 1. 


\section{Figure 1}

PRISMA Chart of Literature Review Process

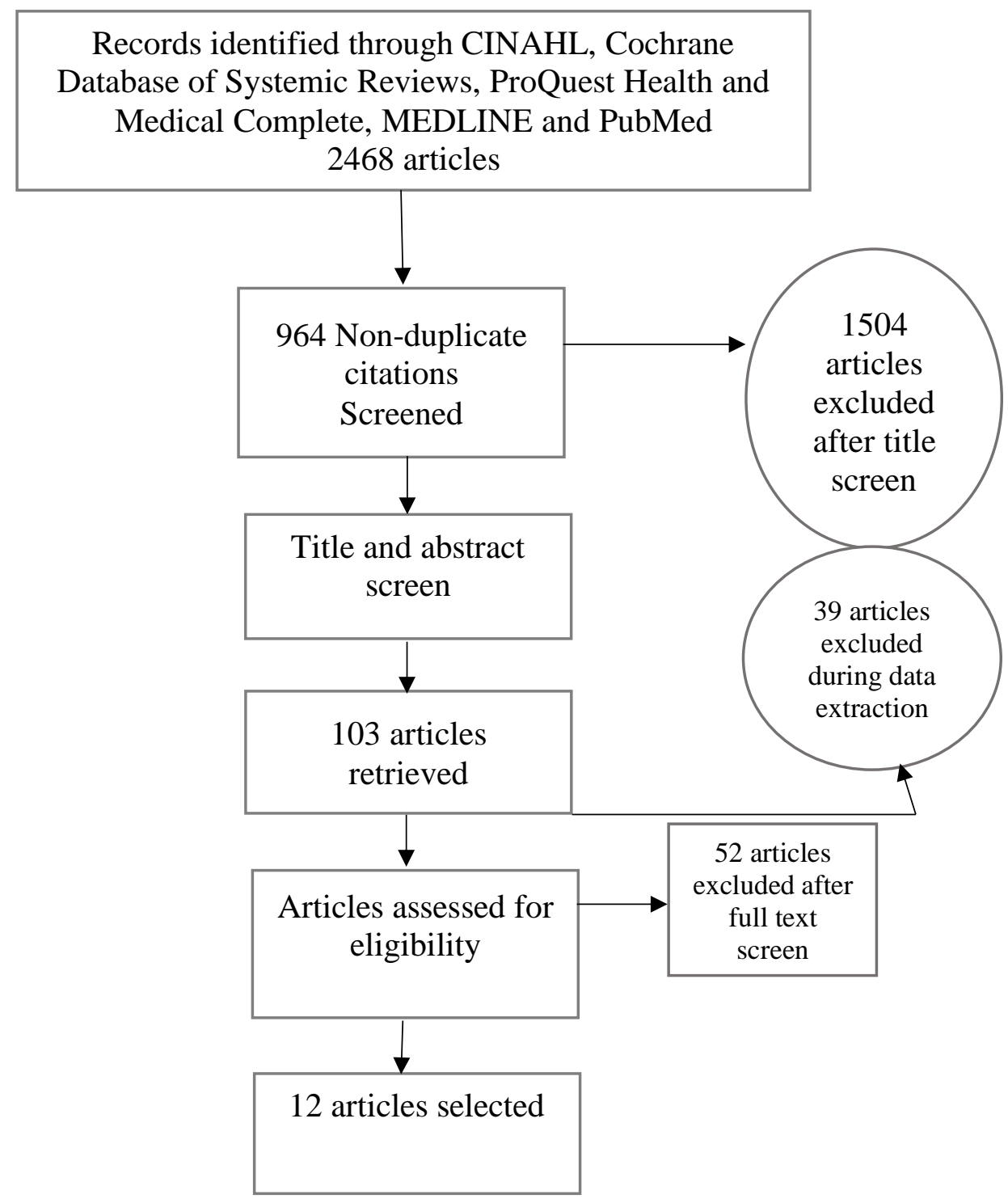

Determining the hierarchy of each article was a vital process during the literature review.

According to Petrisor and Bhandari (2009), evidence hierarchy allows one to locate and rank evidence sources based on the strength of the evidence. Figure 2 illustrates a seven-level hierarchy (Concato et al., 2010). The evidence table presented in Appendix A shows the different evidence levels for the selected articles. 


\section{Figure 2}

Hierarchy of Evidence (Concato et al., 2010).

\section{Hierarchy of Evidence}

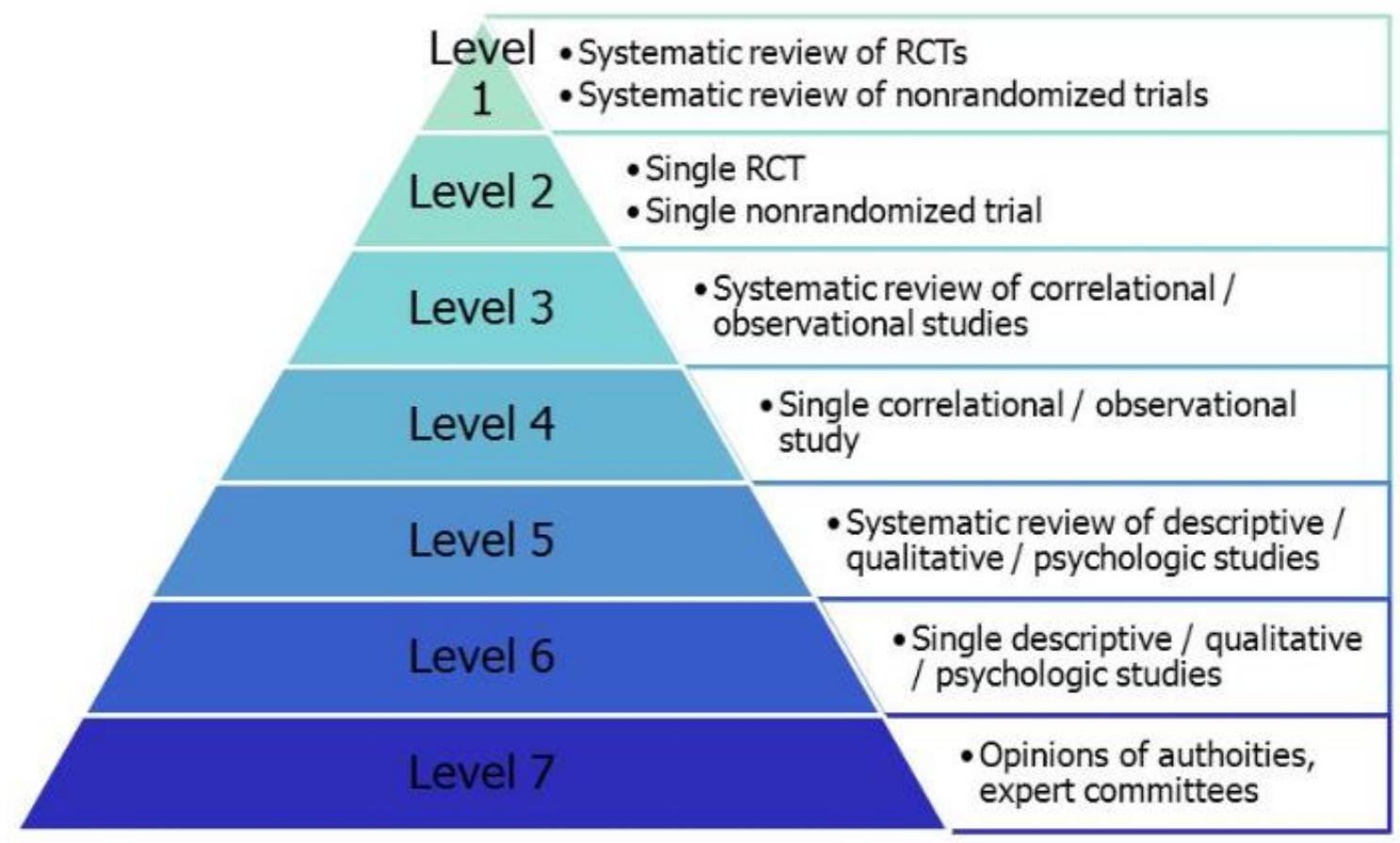

\section{Themes from the Literature}

This section includes several themes identified during the evaluation of the selected literature for the project. Revealed themes and subthemes were based on previous and current empirical research related to patient satisfaction, patient engagement, effective communication, and bedside handoff reports (Evans et al., 2012; McAllen et al., 2018; Ofori-Atta et al., 2015; Radtke, 2013; Rush, 2012). The themes discussed the risks, complications, interventions, or evidence-based approaches for patient satisfaction. McAllen et al. (2018) and Evans et al. (2012) both emphasized that bedside handoff reports help prevent adverse events and allow nurses to check the patient's status quickly. The significance in the transfer of information during a 
nursing transition in care was repeated frequently throughout the literature review. Handoffs that miss patient information can lead to medication errors, poor patient outcomes, and low satisfaction levels. Radtke (2013) illuminated the need for a standardized method of relaying information about patients between nurses and healthcare providers in the same facility. Furthermore, the identified subthemes included strategies to minimize miscommunication, promote accountability, and decrease patient and family anxieties (Ofori-Atta et al., 2015; Rush, 2012).

\section{Practice Recommendations}

The achievement and maintenance of patient satisfaction are crucial to nursing practice. The sustainability of patient satisfaction requires education interventions — particularly regarding communication between nurses and patients (Chapman, 2011). Norouzinia et al. (2016) stated that communication has many aspects that influence how patients share their experiences. Through bedside handoff reports, it is possible to boost the relationship between healthcare providers and patients (Maxson et al., 2012). This improvement is attributed to open conversations that make patients feel more involved throughout the treatment process (Maxson et al., 2012). Previous scholars have indicated that the enhancement of relationships between patients and their caregivers leads patients to have better perceptions of healthcare, which ultimately leads to improved treatment outcomes (Norouzinia et al., 2016). Based on the evidence presented in the themes above, bedside handoff reports are a practical approach for the patient's satisfaction, and most importantly, for better healthcare.

According to McAllen et al. (2018), miscommunication between care providers results in poor outcomes and low patient satisfaction. The implementation of bedside handoff reports resulted in positive outcomes, such as meaningful and critical patient-nurse exchanges (McAllen 
et al., 2018). Additionally, patients' involvement in the treatment process helps to boost their satisfaction (Chapman, 2011). These reports enhanced communication between the care providers, which helped equip them with skills that not only promoted patient satisfaction but also enabled the patients to engage in productive self-management of chronic diseases and adhere to their recommended treatment (Levinson et al., 2010). For example, Evans et al. (2012) indicated that patients could manage their conditions through self-management activities, such as verifying changes in their urine color.

All articles supported that bedside handoff reports should be practiced between nurses and other healthcare staff within a facility to improve the satisfaction of patients, and most importantly, the quality of care that they receive. The literature showed that the traditional handoff led to lapses in communication, thereby leading to medical errors and miscommunication among the staff. This recommendation was a theme in the varied literature sources that led to the current selection of the intervention related to the PICOT question.

\section{Project Setting}

This evidence-based project took place at a nonprofit, Southern California hospital that serves the San Fernando Valley. It is a 153-bed secondary community hospital that delivers care to adult and geriatric patients with medical or surgical needs. The hospital serves a diverse population which includes patients from urban, suburban, and rural communities. The organizational need was based on focus groups and phone interviews from the community (e.g., health agencies, social service providers, and local government organizations). The KEYGROUP identified the needs of increased marketing regarding the services that the hospital provided, including mental health services and chronic care management. 
The Los Angeles community hospital had several strengths and weaknesses. Three strong attributes of the facility were the commitment to maintaining advanced technology, the quality transparency dashboard, and the dedication and availability of the physicians. However, there were still areas in which the hospital had opportunities for growth and performance, such as improved professional development and the potential to become a member of the top 100 hospitals by improving patient satisfaction scores. The hospital faced threats such as competition from other organizations, such as Hospital Corporation of America and Dignity Health. The SWOT Analysis table in Appendix B shows the information on the strengths and weaknesses of the institution, as well as opportunities and threats to the institution.

The organization is well-known for its transformational leaders and the utilization of evidence-based strategies. The institution uses a divisional organization structure of several departments with various functions, such as the clinical lab, pharmacy, surgical services, 24-hour basic emergency care, a wound-center, hyperbaric services, radiology, and stroke-certified and JCAHO certified departments. The interprofessional collaboration was vital to the completion of this project. The mission statement is "to deliver compassionate, quality care to patients and better healthcare to communities" (Sherman Oaks Hospital, 2020, para. 1). The goal of the hospital is to deliver patient-centered healthcare with compassion, dignity, and respect for all patients (Sherman Oaks Hospital, 2020). Moreover, the hospital is a physician-founded and led facility that allows practitioners to oversee healthcare needs at each level (Sherman Oaks Hospital, 2020).

\section{Project Overview}

The mission of this project was to improve the experience, health outcomes, and satisfaction of patients. The long-term goal was to improve patient experience, health outcomes, 
and satisfaction through the implementation of bedside handoff reports. The mission statement of the participating hospital is "to deliver compassionate, quality care to patients and better health to communities" (Sherman Oaks Hospital, 2020, para. 1). The mission and vision of the organization were interlinked with the vision and mission of this project in that they both focus on improving patient outcomes and satisfaction. The short-term objectives of the project included the following:

- Increase in HCAHPS scores of $2 \%$ in one month

- Identify potential barriers in implementing bedside handoff reports intervention Long-term objectives included:

- Increase HCAHPS scores from $73 \%$ to $78 \%$ in two months

- Increase positive responses received during the day nurse manager/clinical supervisor rounding by $10 \%$ in two months

The risks and unwanted consequences of the project included unwilling respondents and resistance to change by nurses. Additionally, the project could have failed to meet the set timeframe due to delays caused by stakeholders' actions.

\section{Project Plan}

The Plan, Do, Study, Act framework guided the implementation of this evidence-based project. This model provided a structure in the methods used to obtain and interpret information to improve the practices, products, and services of the hospital. The merit of this model was that small changes took place with an adequate assessment of their impacts (Taylor et al., 2014). The model was particularly useful in implementing small elements of the projects and measuring the impact of components, such as bedside reports and patient satisfaction. 
The first step, Plan, included identifying the problem (patient satisfaction) and developing guidelines for improvement. The second step, Do, involved implementing the preimplementation plan and followed the specific guidelines stated in the project proposal. The third step, Study, led to an assessment of the preintervention/post-intervention data collected. The findings provided the hospital leadership team with suggested strengths, weaknesses, and areas for growth opportunities. Then the last step, Act, looped the process to select areas for monitoring and adjusting for sustained improvement. This model could be used for individual and organizational changes related to patient satisfaction, as described in Appendix E.

Interprofessional collaboration is when several healthcare providers or workers from varied professional backgrounds work cohesively with patients, families, caregivers, and communities (Vega \& Bernard, 2017). This led to the delivery of higher quality, patient-centered care. This interprofessional collaboration in the project occurred with the hospital manager, director, administration, and nursing preceptor. The expected benefits of the partnership included supervised guidance, administrative support, brainstorming, and improvement in patient outcomes (Vega \& Bernard, 2017). The barriers to the implementation of the project included a lack of funds and the nurses' resistance to change. The budget for the project is presented in Appendix D.

\section{Project Evaluation Plan}

In this part of the evidence-based project, the identified outcomes noted in the PICOT question are discussed. The following sections include the recruitment and selection of participants, including the inclusion and exclusion criteria, the data collection and analysis processes, the methods for determining the success of the project, the setting and environment of the project, data storage, and the integrity of the overall process. In later sections, the procedures 
associated with missing data and data security are described. The last sections in this discussion include the considerations related to the protection of human rights and the privacy of participants' information. The purpose of this evidence-based project was to evaluate whether the implementation of nursing bedside handoffs compared to the current practice of the desk handoff report would improve patient satisfaction scores by $10 \%$ in a medical-surgical unit within two months.

\section{Recruitment and Selection of Participants}

The method for recruiting participants was convenience sampling. The rationale for using this method was the location of the hospital where the project took place, patients' availability, and their willingness to participate in the EBP project (Etikan et al., 2016). Each admitted patient received an informational flyer regarding the purpose of the project. Participant requirements included being 18 to 65 years of age, currently being admitted on the medical-surgical floor, having the potential for home discharge (two to four days), and the ability to read and write English. The exclusion criteria included admission into other units, including intensive care, the emergency room, and pediatrics; patients mentally altered from medication or neurological issues; and patients over the age of 65. The $\mathrm{G}^{*}$ Power Software, version 3.1.9.2., used a large effect size, with an alpha level of .05 , and a power of $80 \%$ to select an estimated minimal sample size of $34(n=34)$ to answer the clinical question.

\section{Data Collection}

The project occurred after receiving permission from the University of St. Augustine for Health Sciences (USAHS) Evidence-Based Practice Review Council and the facility (see Appendix C). Informational flyers were placed in the nurses' lounge, bathrooms, nurses' stations, and near-patient elevators. Each admitted patient received an informational flyer and gave 
consent to participate. Patients' provided verbal and written consent after getting an explanation of the evidence-based project. The written consent described the project's purpose, risks, benefits, privacy, and confidentiality procedures. Any questions that potential participants had were answered before they began the four-item demographic survey. All participants understood that participating in the project was voluntary and knew that they could withdraw without penalty. Patients then completed an I-PAHC pretest, which covered five domains of care: nurse communication, physician communication, physical environment, pain management, medication, and symptom communication. The items were scored using a Likert scale that ranged from 1 (never) to 4 (always).

The participants completed their pretests upon admission to the unit, and they completed their posttests on the day of discharge. The tests were placed inside a manila envelope and securely transported in a briefcase. The hard copies of the tests remained secure in a locked home file cabinet. The questionnaires are scheduled to be destroyed at the required time (three years, August 2023) per St. Augustine's University’s protocol.

\section{In-Patient Assessment of Healthcare and Out-patient Assessment of Healthcare Survey}

The instrumentation used for data collection in this project was the I-PAHC and O-PAHC developed by Dr. Elizabeth Bradley. Permission to use the instruments for the project was granted by the author on May 28, 2020. Dr. Bradley requested that the instrumentation used in the manuscript be cited. The I-PAHC portion of the tool was appropriate for the project because it is a tool for inpatients. The I-PAHC falls on a Likert scale ranging from 1 (never) to 4 (always) are in the I-PAHC questionnaire. See Appendix F for the instrument.

Validity. Leedy and Ormrod (2011) showed the validity of the I-PAHC tools using the construct and convergent cogency of the content. Webster et al. (2011) used the summary scores 
of the questionnaires to evaluate the convergent validity. This was achieved by reviewing the statistical analysis of Pearson correlation (Pearson $r$ ) with the responses of the patient's overall evaluation items. The correlations of the summary scores for the scales and patients' evaluation were $.0 .40(p=0.05)$.

Reliability. The Cronbach's alpha coefficients for the scales related to I-PAHC surveys surpassed 0.70 (Webster et al., 2011). This suggested excellent reliability scales in connection to communication with nurses and doctors, as well as pain management and medication factors (Webster et al., 2011)

\section{Data Analysis}

The pretest and demographic questionnaires were given to the participants upon admission to the medical-surgical unit. The demographic survey data included age, gender, diagnosis, educational level, and admission/discharge dates. The descriptive statistics were used to explain and document the chosen population and sample size (Leedy \& Ormrod, 2011). The authors presented the descriptive statistics in graphics such as tables, figures, and scatter plots. The means, median, and mode were displayed to define the participants' categorical responses (Leedy \& Ormrod, 2011). The participants completed the posttest on the day of their discharge home.

Paired Sample $t$-test. A paired sample $t$-test was used to analyze the participant's hospital experience upon admission and discharge. The paired $t$-test evaluated the statistical significance by comparing the pretest and posttest; statistical significance was noted if the $p$ value was <. 05. Eight sub-questions were entered and coded in a Microsoft Excel spreadsheet and exported into the Statistical Package for the Social Sciences (SPSS) 26. 
Pearson Correlation Test (Pearson's $r$ ). A regression model helped to determine whether nursing satisfaction was correlated with the hospital rating score following hospital care. Linear regression helped model the relationship between the variables by fitting a linear equation to observed data. This test is a parametric measure that evaluates the strength and direction of relationships between pairs of continuous variables (Leedy \& Ormrod, 2011). In this project, the participants responded to standard questions during a bedside handoff report that was performed by the nurses to identify whether there was statistical evidence of a relationship between the variables (Leedy \& Ormrod, 2011). A magnitude of the correlation (how close to -1 or +1 ) indicated the strength of the relationship. A correlation of -1 would indicate a negative linear relationship, 0 would indicate no relationship, and +1 would demonstrate a positive linear relationship (Leedy \& Ormrod, 2011).

\section{Data Storage and Integrity}

Hard copies of the de-identified demographic I-PAHC surveys were downloaded and backed up to a $\mathrm{CD}$, then transferred to a password-protected folder. The hard copies of the demographic and I-PAHC surveys were stored in a home office inside a locked file cabinet. The collected data will continue to be secured and will be destroyed in the specified time frame stated by University of St. Augustine for Health Sciences Review Council. The digital copies will be destroyed using the Active @ KillDisk, which is a disk sanitation and partition eraser.

Handling of Missing Data. Missing data is information not stored in a variable of interest (Kang, 2013). The absence of data and assigned -99 was analyzed. If greater than $50 \%$ of the answers were missing during the coding phase, the questionnaire was deleted, and its data was not used. Utilizing this method allowed the statistical power used to be maintained while also avoiding the bias that could reduce the sample size's representation (Kang, 2013). 
Data Security. Several practices were implemented for data security during the analysis stage of the project. Confidential data was stored on a flash memory device, which remains in an undisclosed, locked safe. All passwords were updated, encrypted, and protected, and were never shared or left on paper or workstations. A laptop used for the project was configured to lock after 10 minutes of inactivity to reduce the risk of theft or unauthorized usage. Additionally, all collected data was stored on a password-encrypted laptop within a compressed and encrypted file. All de-identified information will be destroyed according to St. Augustine University Review Council guidelines.

\section{Protection of Human Rights}

Participants were guaranteed protection and privacy by following the guidelines written in the Belmont Report (Zucker, 2013). All participants provided their written, informed consent before participating in the project. The instructions included the purpose of the project, risks related to loss of de-identified hard copies and the flash drive, and the ability of participants to withdraw from the project if they felt uncomfortable, without repercussion. No retaliation, personal, or professional harm occurred to any participant for not participating in or withdrawing from the project. Participants' concerns or questions related to the project were addressed. The returned demographic questionnaires and I-PAHC surveys were de-identified using codes consisting of the first two letters of the participant's last name, the last four digits of their cell phone number, and the year of the project. Finally, any unanticipated problems or changes related to the project were reported immediately.

\section{Project Findings}

Ultimately, it appears that the measurement of patient satisfaction is vital to the delivery of high-quality care. Such measures help nursing management, hospital administration, and staff 
understand and meet patients' needs and expectations. Patient satisfaction is connected to conformity, decreased medical services usage, reduced litigation, and positive health outcomes (Xesfingi \& Vozikis, 2016). The purpose of this evidence-based project was to evaluate whether the implementation of nursing bedside handoffs, compared to the current practice of the desk handoff reports, would improve patient satisfaction scores by $10 \%$ in a medical-surgical unit within two months. In this section of the paper, the statistical data results of the project are discussed.

\section{Participants}

During the pretest, participants provided demographic information by answering four questions. Participants consisted of females $(n=14)$ and males $(n=12)$. The sample consisted of 26 participants between 18 to 24 years of age $(n=4), 25$ to 34 years of age $(n=5), 35$ to 44 years of age $(n=4), 45$ to 54 years of age $(n=6)$ and 55 to 64 years of age $(n=7)$. The participants' education was divided into six categories: high school or GED $(n=7)$, some college $(n=4)$, associate's degree $(n=4)$, bachelor's degree $(n=6)$, master's degree $(n=4)$ and doctoral degree $(n=1)$. The participants self-reported as White $(n=8)$, Black, Caribbean, or African American $(n=10)$, and Hispanic $(n=8)$. Prior to statistical analysis, the questionnaires were classified according to gender, educational background, age, nursing experience, and ethnicity.

Two paired-samples $t$-tests helped answer the clinical question and determine the level of patient satisfaction of a hospital stay by services provided by nurses and doctors. G*Power Software, Version 3.1.9.2, calculated a large effect size, an alpha level of .05, and a power of $80 \%$, which helped to estimate the minimum sample size of 34 to answer the EBP PICOT question. The analysis showed that the PICOT question was underpowered $(n=26)$; therefore, 
the sample size requirement was not met. Furthermore, noted threats to internal validity included sample size, history (participants did readings on their own), maturation (just by getting older), testing (memorized questions from pretest), and natural statistical regression (extremely high or low scores on the pretest naturally move closer to mean on the post).

A paired sample $t$-test compares the means of two scores. In this project, the test compared pre and post patient's satisfaction levels during a hospital stay while in the care of nurses, doctors, and health officers. The three variables for the SPSS data file represented two measurements from each participant $(n=26)$. The two mean scores for the pretest and posttest were compared to determine if they were significantly different, followed by a paired sample $t$ test to conclude whether they were different due to chance alone or if there was a true difference.

\section{Satisfaction Level - Nurses}

The results of the paired sample $t$-test revealed a statistically significant $(t(25)=-4.606$, $p<.05)$, (p-value .000052) difference between patients' satisfaction with nurses before and after the intervention. The mean pretest for satisfaction level of patients during the first visit, when cared for by a nurse $(M=3.32, \mathrm{SD}=0.39)$, was significantly different from the patients' mean satisfaction level during the second visit $(M=3.59, \mathrm{SD}=0.35)$. The analysis indicated a change in the mean level, with the patients strongly agreeing that they were treated with courtesy and respect, carefully listened to, and that the nurses explained things well (see Table 1).

\section{Table 1}

Level of Patient Satisfaction of a Hospital Stay by Services Provided by Nurses

\begin{tabular}{lcccccccc}
\hline \multicolumn{1}{c}{$\begin{array}{c}\text { Before } \\
\text { Intervention }\end{array}$} & \multicolumn{2}{c}{$\begin{array}{c}\text { After } \\
\text { Intervention }\end{array}$} & \multicolumn{2}{c}{$95 \%$ CI } \\
\hline Outcome & $M$ & $S D$ & $M$ & $S D$ & $n$ & & $t$ & $d f$ \\
Satisfaction & 3.32 & 0.39 & 3.59 & 0.35 & 26 & {$[-0.391,-0.149]$} & $4.606^{*}$ & 25 \\
\hline$* p=0.05$ & & & & & & & &
\end{tabular}




\section{Satisfaction Level - Doctors/Health Officers}

The results of the second paired sample $t$-test indicated a statistically significant $(t(25)=$ $-6.024, p<.05)$, (p-value <.00001) difference in patients' satisfaction with doctors before and after the intervention. The mean pretest of patients' satisfaction level during the first visit, when cared for by a doctor/health officer $(\mathrm{M}=3.28, \mathrm{SD}=0.36)$, was significantly different from the participants' mean satisfaction level during a second visit $(M=3.61, \mathrm{SD}=0.31)$. These findings revealed a change in patients' perceptions when they are treated with courtesy and respect, are carefully listened to, and are cared for by the doctors and health officers who explained topics and addressed concerns clearly (see Table 2).

Table 2

Level of Patient Satisfaction of a Hospital Stay by Services Provided by Doctors/Health Officers

\begin{tabular}{lcccccccc}
\hline \multicolumn{7}{c}{$\begin{array}{c}\text { Before } \\
\text { Intervention }\end{array}$} & \multicolumn{2}{c}{ After } \\
Intervention
\end{tabular}

\section{Discussion of Findings and Implications}

The outcomes of the project supported previous and current literature and other evidencebased studies. This indicates a connection between positive patient experiences and their satisfaction, which leads to improved clinical outcomes, patient safety, decreased admission rates, and regimen compliance (Richter \& Muhlestein, 2017). The outcomes were significant because they supported current literature regarding evidence-based strategies about medicalsurgical settings related to patient satisfaction and experience. Trzeciak et al. (2016), Betts et al. (2016), and Smith and Choma (2017) demonstrated that implementing patient satisfaction strategies allowed hospitals to concentrate on specific aspects and clinical outcomes. 


\section{Limitations of the Project}

Limitations describe the restrictions beyond one's control (Simon \& Goes, 2011). Three constraints influenced the results of the project: Any limits and inabilities of the environment due to the COVID-19 pandemic, the small sample size, and the project timeframe. It was impossible to control the circumstances surrounding this project related to the pandemic, which required renegotiations with the preceptor about conducting the project in conjunction with new mandated guidelines. Additionally, it was unfeasible to control the environment in which the participants provided their answers during the admission or discharge processes. It was probable that the participants responded differently depending on the time of day and conditions that occurred during their admission or discharge (Leedy \& Ormrod, 2011).

The second limitation of this project was the small participant group. The current EBP project was limited to one medical-surgical unit. The participant group was $26(n=26)$, with an even division of 12 males $(n=12)$ and 14 females $(n=14)$, which caused the project to be underpowered. A larger participant group would have permitted higher evaluation of the average values of data, avoided potential errors, and minimized bias (Leedy \& Ormrod, 2011). Larger participant groups could have improved the accuracy of the values and decrease outliers (Leedy \& Ormrod, 2011). In the current project, a larger participant group related to patient satisfaction would have required considerable financial and time resources. The selection of participants during the admission and discharge process may have transferrable findings to other patient populations and units.

The third limitation of the project was the short timeframe of two months, which was considered an evidence-based project, as opposed to a longitudinal project, which typically occurs over a long time (Leedy \& Ormrod, 2011). The relationship between patient satisfaction 
and bedside handoff reportedly could not be determined. If a longitudinal project had been conducted, it could have measured the behavior of nursing staff and the consistency of performing the bedside handoff reporting over a more extended period. The longitudinal project employs repeated measures and follows individuals for an extended time, typically a year or decade (Caruana et al., 2015). A longitudinal project could assist the hospital in evaluating the participants' behaviors by assessing the relationships between variables and documenting the outcomes over varying timeframes (Caruana et al., 2015). Such findings may help nursing management teams to develop strategies to meet the staff's evolving needs and help improve patient satisfaction.

\section{Conditions Acknowledged when Reporting Findings}

In the weeks when the COVID-19 pandemic unfolded in the community, several challenges occurred when collecting data and analyzing the project's findings. Numerous meetings with the preceptor and nurse manager took place to discuss the direction of the project. The priority was to ensure that staff would adhere to proper social distancing while implementing bedside handoff reports. Another challenge was the influx of patients, which resulted in a shortage of nursing staff, an upheaval of standard nursing policies, and the development of new evidence-based solutions to the challenges of the unit. Many nursing students' clinical rotations were canceled or suspended in response to the COVID-19 crisis. So, only a small window of opportunity opened, which allowed the completion of the project versus finishing a policy-related project online.

\section{Implications of the Project}

This evidence-based project posed significant implications for medical-surgical nurses because they provide front-line care to patients. The data analysis showed that bedside handoff 
reporting made a difference in the patients' perceptions and satisfaction with care. A significant difference was discovered in the patient scores related to the care and comfort with the nurses and physicians. The patient satisfaction education program served as the intervention for this project, and it can also be utilized in other hospital units, such as the emergency room, intensive care, the direct observation unit, and postpartum care. This intervention could also be implemented in clinical practice to educate students as well as current and future nurses at the hospital, based on the significance of the hospitalized patient satisfaction experience.

Theoretical Implications. Lewin's (1951) change theory guided the project by explaining how to implement change in the medical-surgical unit. This theory involves three steps — freeze, moving, and refreezing — needed to achieve a permanent change in clinical nursing practice. This theoretical foundation allowed for the improvement of the unit's existing strategies while also implementing a new method that incorporates patient satisfaction into the nurses' clinical practices. The educational intervention permitted nurses to recognize and learn how the patient experience and satisfaction affects the hospital's community standing, financial status, and healthcare outcomes.

Practical Implications. One crucial practical implication of the findings was related to the nurses' clinical practice. In the clinical setting, many nurses believe that they are too busy to participate in and implement evidence-based nursing practices and activities (Penz \& Bassendowski, 2006). After making changes to include both nursing staff perspectives and feedback regarding patient satisfaction and workloads, the nursing staff reported that they required additional time, education, and training for continued patient satisfaction. Recommendations to implement this topic during morning and evening nursing huddles before the beginning of the shift as a method for nursing management to learn strategies for execution in 
clinical practice followed. This practice would ensure buy-in from the staff — both morning and evening staff — to sustain the program and increase the patient satisfaction scores, eventually, by $50 \%$.

\section{Plans for Dissemination}

Edwards (2015) emphasized that developing a dissemination strategy is a critical part of the evidence-based process. The first step was sharing the generalized version of this project's findings with the hospital administrator, followed by the nurse manager and nursing staff. This took place during a 30-minute PowerPoint presentation on Zoom, which allowed feedback from all parties. Individuals who could not attend the meeting received an email that summarized the findings. An oral presentation occurred to meet the requirements for the University of St. Augustine for Health Sciences. Future monitoring is required to validate the practice's sustainability of the practice of bedside handoffs.

The project findings will be disseminated through a poster presentation at California's Board of Nursing annual state conference (nursing practice committee), proposed for October 2020. The project will be submitted to a peer-reviewed nursing journal to be considered for further dissemination of the results. The first peer-reviewed nursing journal is the American Journal of Nursing, which is the oldest nursing journal in the United States.

\section{Conclusion}

The implementation of bedside handoff contributes to patient satisfaction. Other traditional forms of reporting may lead to lapses in communication, which can affect patients negatively, including medical errors, lengthened hospital stays, and high financial costs. Based on the evidence presented concerning bedside handoff reports, this intervention promotes improved patient engagement in the treatment processes and healthcare decisions. The findings 
of the project may be beneficial to nurses by encouraging casual conversations and developing strategies related to decreased miscommunication with their patients. Ten percent or more improvement in patient satisfaction scores was expected and achieved at the hospital after the execution of the intervention.

Patient satisfaction and experience metrics deliver information on the ability of healthcare providers to meet patient expectations. Such measurements offer insights on patients' viewpoints and behavioral intentions. Enhanced patient satisfaction increases clinical outcomes and patient loyalty for the surrounding community of the hospital. Bedside handoffs, along with patient engagement, allows for a smoother and clearer transition from one nurse to another. The purpose of this evidence-based project was to evaluate whether the implementation of nursing bedside handoffs, compared to the current practice of desk handoff reports, would improve patient satisfaction scores. The project findings validated those of previous scholars such as Berkowitz (2016), Webster et al. (2011), and Ford and Heyman (2017). As a result, the goal for all advanced practice nurses should be to continue educating nursing staff in conducting bedside shift handoffs to engage patients and families in the healthcare processes and to ultimately improve care outcomes. 


\section{References}

Ahmed, Z., Saada, M., Jones, A. M., \& Al-Hamid, A. (2019). Medical errors: Healthcare professionals' perspective at a tertiary hospital in Kuwait. PLOS One, 14(5), 5-31

Berkowitz, B. (2016). The patient experience and patient satisfaction: Measurement of a complex dynamic. Online Journal of Issues in Nursing.

http://ojin.nursingworld.org/MainMenuCategories/ANAMarketplace/ANAPeriodicals/OJ IN/TableofContents/Vol-21-2016/No1-Jan-2016/The-Patient-Experience-and-PatientSatisfaction.html

Betts, D., Balan-Cohen, A., Shukla, M., \& Kumar, N. (2016). The value of patient experience: Hospitals with better patient-reported experience perform better financially. Deloitte Center for Health Solutions. https://www2.deloitte.com/us/en/pages/life-sciences-andhealthcare/articles/hospitals-patient-experience.

Bleich, S. (2009). How does satisfaction with the health-care system relate to patient experience? Bulletin of the World Health Organization, 87(4), 271278. https://doi.org/10.2471/blt.07.050401

Caruana, E. J., Roman, M., Hernández-Sánchez, J., \& Solli, P. (2015). Longitudinal studies. Journal of Thoracic Disease, 7(11), E537-E540. https://doi.org/10.3978/j.issn.2072-1439.2015.10.63

Chapman, K. (2011). Improving communication among nurses, patients, and physicians. American Journal of Nursing, 109, 21-25. https://doi.org/10.1097/01.naj.0000362013.53342.17 
Concato, J., Shah, N., \& Horwitz, R. (2010). Randomized, controlled trials, observational studies, and the hierarchy of research designs. New England Journal of Medicine, 342 (25), 1887-1892. https://pubmed.ncbi.nlm.nih.gov/10861325/

Data.Medicare.gov. (2018). Patient survey (HCAHPS) - National. Retrieved from https://data.medicare.gov/Hospital-Compare/Patient-survey-HCAHPS-National/99uew85f

Edwards, D. (2015). Dissemination of research results: On the path to practice change. Canadian Journal of Hospital Pharmacy, 68(6), 465-469. https://doi.org/10.4212/cjhp.v68i6.1503

Etikan, I., Musa, S., \& Akassim, R. (2016). Comparison of convenience sampling and purposive sampling. American Journal of Theoretical and Applied Statistics, 5(1), 1-4. https://doi.org/10.11648/j.ajtas.2016501.11

Evans, D., Grunawalt, J., McClish, D., Wood, W., Friese, C. (2012). Bedside shift-to-shift nursing report: Implementation and outcomes. MEDSURG Nursing, 21(5), 281-292. https://pubmed.ncbi.nlm.nih.gov/23243785/

Ford, Y., \& Heyman, A. (2017). Patients' perceptions of bedside handoff. Journal of Nursing Care Quality, 32(1), 15-24. https://doi.org/10.1097/ncq.0000000000000201

Goh, M., Ang, E., Chan, Y., He, H., \& Vehvilainen, K. (2016). A descriptive quantitative study on multi-ethnic patient satisfaction with nursing care measured by the revised humane, caring scale. Applied Nursing Research, 31, 126-131. https://doi.org/10.1016/j.apnr.2016.02.002

Gonçalves, M., Rocha, P., Anders, J., Kusahara, D., \& Tomazoni, A. (2016). Communication and patient safety in the change-of-shift nursing report in neonatal intensive care units. 
Texto \& Contexto-Enfermagem, 25(1). 161- 169

https://www.redalyc.org/pdf/714/71444666010.pdf

Healthcare News. (2020, June). Putting patient experience at the center of care.

https://www.healthcareitnews.com/news/asia-pacific/putting-patient-experience-centercare

Hughes, R. (Ed.). (2012). Patient safety and quality: An evidence-based handbook for nurses (Vol. 3). Agency for Healthcare Research and Quality.

Joint Commission. (2018). The national patient safety goals. http://www.jointcommission.org/standards_information/npsgs.aspx

Jones, T. (2016). Outcome measurement in nursing: Imperatives, ideals, history, and challenges. Online Journal of Issues in Nursing, 21(2). 465-476. https://ojin.nursingworld.org/MainMenuCategories/ANAMarketplace/ANAPeriodicals/O JIN/

Kang, H. (2013). The prevention and handling of the missing data. Korean Journal of Anesthesiology, 64(5), 402-406. https://doi.org/10.4097.kjae.2013.64.5.402

Karaca, A., \& Durna, Z. (2019). Patient satisfaction with the quality of nursing care. Nursing Open, 6(2), 535-545. https://doi.org/10.1002/nop2.237

Leedy, P., \& Ormrod, J. (2011). Practical research: Planning and design (10th Ed.). Pearson/Merrill Prentice Hall.

Levinson, W., Lesser, C. S., \& Epstein, R. M. (2010). Developing physician communication skills for patient-centered care. Health Affairs, 29(7), 1310-1318. https://www.healthaffairs.org/doi/full/10.1377/hlthaff.2009.0450 
Lewin, K. (1951). Problems of research in social psychology. In D. Cartwright (Ed.), Field theory in social science. Harper \& Brothers.

Maxson, P., Derby, K., Wrobleski, D., \& Foss, D. (2012). Bedside nurse-to-nurse handoff promotes patient safety. Medical-Surgical Nursing, 21(3), 140. www.aahs.org/wpcontent/uploads/Bedside-Nurse-to-Nurse-Handoff-Promotes-Patient-Safety.pdf

McAllen, E., Stephens, K., Swanson-Biearman, B., Kerr, K., \& Whiteman, K. (2018). Moving shift report to the bedside: An evidence-based project. Online Journal of Issues in Nursing, 23(2). https://ojin.nursingworld.org/MainMenuCategories/ ANAMarketplace/ANAPeriodicals/OJIN/

Norouzinia, R., Aghabarari, M., Shiri, M., Karimi, M., \& Samami, E. (2016). Communication barriers perceived by nurses and patients. Global Journal of Health Science, 8(6), 65-74. https://doi.org/10.5539/gjhs.v8n6p65

Ofori-Atta, J., Binienda, M., \& Chalupka, S. (2015). Bedside shift report: Implications for patient safety and quality of care. Nursing, 45(8), 1-4. doi:

10.1097/01.NURSE.0000469252.96846.1a

Patwardhan, A., \& Spencer, C. (2012). Are patient surveys valuable as a service-improvement tool in health services? An overview. Journal of Healthcare Leadership, 4, 33-46. https://doi.org/10.2147/jhl.s23150

Penz, L. \& Bassendowski, S. (2006). Evidence-based nursing in clinical practice: Implications for nurse educators. Journal of Continuing Education in Nursing, 37(6), 250-254. https://sss.researchgate.net/publication/665143

Petrisor, B. A., \& Bhandari, M. (2009). Imaging after trauma to the pelvis and hip. Bmj, 338(Mar11 2). doi:10.1136/bmj.b289 
Petrisor, B., \& Bhandari, M. (2009). Imaging after trauma to the pelvis and hip. British Medical Journal, 338, 289-b289. https://doi.org/10.1136/bmj.b289

Radtke, K. (2013). Improving patient satisfaction with nursing communication using bedside shift report. Clinical Nurse Specialist, 27(1), 19-25. https://pubmed.ncbi.nlm.nih.gov/23222024/

Richter, J., \& Muhlestein, D. (2017). Patient experience and hospital profitability: Is there a link? Health Care Management Review, 42(3), 247-57. https://doi.org/10.1097/HMR.0000000000000105

Rush, S. (2012). Bedside reporting: Dynamic dialogue. Nursing Management, 43(1), 40-44. https://doi.org/10.1097/01.NUMA.0000409923.61966.ac

Sherman Oaks Hospital. (2020). Hospital rankings inpatient experience. https://health.usnews.com/best-hospitals/area/ca/sherman-oaks-hospital6933516\#rankings

Simon, M., \& Goes, J. (2011). Dissertation and scholarly research: Recipes for success. doi: $10.3138 /$ jsp.43.1.39

Smith, M., \& Choma, T. (2017). Patient satisfaction in musculoskeletal medicine. Current Review Musculoskeletal Medicine, 10(2), 207-2011. doi:10.1007/s12178-017-9403-x

Taylor, M., McNicholas, C., Nicolay, C., Darzi, A., Bell, D., \& Reed, J. (2014). Systematic review of the application of the plan-do-study-act method to improve quality in healthcare. BMJ Quality \& Safety, 23(4), 290-298. https://doi.org/10.1136/bmjqs-2013001862

Trzeciak, S., Gaughan, J.P., Bosire, J., \& Mazzarelli, A.J. (2016). Association between Medicare summary star ratings for patient experience and clinical outcomes in U.S. hospitals. 
Journal of Patient Experience, 3(1), 6-9. https://doi.org/10.1177/2374373516636689

Vega, C., \& Bernard, A. (2017). Interprofessional collaboration to improve health care: An introduction. Medscape CME \& Education. https://www.medscape.org/viewarticle/857823\#

Webster, T., Mantopoulos, J., Jackson, E., Cole-Lewis, H., Kidane, L., Kebede, S., Abebe, Y., Lawson, R., \& Bradley, E. (2011). A brief questionnaire for assessing patient healthcare experiences in low-income settings. International Journal for Quality in Health Care, 23 (3), 258-268. https://doi.org/10.1093/intqhc/mzr019

Xesfingi, S., \& Vozikis, A. (2016). Patient satisfaction with the healthcare system: Assessing the impact of socioeconomic and healthcare provision factors. BMC Health Services, 16(94), 1-4. https://doi.org/10.1186/s12913-016-1327-4

Zucker, D. (2013). The Belmont Report. Encyclopedia of Statistical Sciences.

doi:10.1002/0471667196.ess7160 


\title{
Appendix A
}

\author{
Evidence Table
}

\begin{tabular}{|c|c|c|c|c|}
\hline $\begin{array}{l}\text { Narasimhan, M., } \\
\text { Eisen, L. A., } \\
\text { Mahoney, C. D., } \\
\text { Acerra, F. L., \& } \\
\text { Rosen, M. J. } \\
(2016)\end{array}$ & $\begin{array}{l}\text { Radtke } \\
\text { (2013) }\end{array}$ & $\begin{array}{l}\text { Sand- Jecklin } \\
\text { (2013) }\end{array}$ & $\begin{array}{l}\text { Bradley \& Mott } \\
\text { (2014) }\end{array}$ & $\begin{array}{l}\text { Cacal \& Moy } \\
(2013)\end{array}$ \\
\hline $\begin{array}{l}\text { Randomized } \\
\text { control } \\
\text { trial/Quantitative }\end{array}$ & $\begin{array}{l}\text { Patient } \\
\text { satisfaction } \\
\text { (evaluated } \\
\text { with } \\
\text { postdischarge } \\
\text { surveys) }\end{array}$ & & $\begin{array}{l}\text { Quasi- } \\
\text { experimental }\end{array}$ & \begin{tabular}{|l|} 
Randomized \\
Controlled Trial
\end{tabular} \\
\hline Level IV & Level VI & Level III & Level III & Level II \\
\hline $1 \mathrm{~A}$ & $1 \mathrm{~B}$ & $2 \mathrm{~A}$ & $1 \mathrm{C}$ & $1 \mathrm{~A}$ \\
\hline $\begin{array}{l}\text { To evaluate the } \\
\text { effect of a } \\
\text { standardized } \\
\text { worksheet on } \\
\text { physicians' and } \\
\text { nurses' } \\
\text { perceptions } \\
\text { of goals of care } \\
\text { and on patients' } \\
\text { length of stay in } \\
\text { an intensive care } \\
\text { unit }\end{array}$ & $\begin{array}{l}\text { Determine if } \\
\text { standardizing } \\
\text { shift report } \\
\text { using SBAR } \\
\text { improved } \\
\text { patient } \\
\text { satisfaction } \\
\text { with nursing } \\
\text { communicatio } \\
\text { n }\end{array}$ & $\begin{array}{l}\text { Change practice } \\
\text { on medical- } \\
\text { surgical units to } \\
\text { promote safety } \\
\text { and nursing } \\
\text { satisfaction }\end{array}$ & $\begin{array}{l}\text { Formulation of a } \\
\text { policy requiring } \\
\text { bedside reports } \\
\text { to improve } \\
\text { patient safety } \\
\text { and satisfaction } \\
\text { with nursing } \\
\text { communication }\end{array}$ & $\begin{array}{l}\text { To determine if } \\
\text { bedside report } \\
\text { would increase } \\
\text { both patient and } \\
\text { nurse satisfaction }\end{array}$ \\
\hline $\begin{array}{l}\text { The study was } \\
\text { done in the } \\
\text { medical ICU of } \\
\text { Beth Israel } \\
\text { Medical Center, a } \\
\text { 697-bed Teaching } \\
\text { hospital serving } \\
\text { the lower east side } \\
\text { of Manhattan and } \\
\text { Brooklyn }\end{array}$ & $\begin{array}{l}\text { Bedside } \\
\text { reporting was } \\
\text { implemented, } \\
\text { and } 66 \text { Patient } \\
\text { surveys taken } \\
\text { after } \\
\text { discharge } \\
\text { from a } \\
\text { hospital over } \\
\text { three months }\end{array}$ & $\begin{array}{l}\text { Seven medical- } \\
\text { surgical units at a } \\
\text { large teaching } \\
\text { hospital, but } \\
\text { patients } \\
\text { discharging on } \\
\text { the day the study } \\
\text { began (less than } \\
48 \text { hours admitted } \\
\text { were not included }\end{array}$ & $\begin{array}{l}\text { The self-selected } \\
\text { sample included } \\
\text { nine inpatients } \\
\text { (five women, } \\
\text { four men) and } \\
48 \text { self-selected } \\
\text { enrolled/register } \\
\text { ed nursing staff } \\
\text { ( } 47 \text { women, one } \\
\text { man) from three }\end{array}$ & $\begin{array}{l}\text { Critically ill } \\
\text { patients admitted } \\
\text { to a labor and } \\
\text { delivery unit }\end{array}$ \\
\hline
\end{tabular}




\begin{tabular}{|c|c|c|c|c|}
\hline & & & $\begin{array}{l}\text { acute hospital } \\
\text { wards in rural } \\
\text { South Australia }\end{array}$ & \\
\hline $\begin{array}{l}\text { In-person } \\
\text { communication } \\
\text { intervention and } \\
\text { participants were } \\
\text { randomly } \\
\text { assigned to either } \\
\text { an experimental } \\
\text { or control group } \\
\text { and followed up } \\
\text { for nine months }\end{array}$ & $\begin{array}{l}\text { Medical- } \\
\text { surgical } \\
\text { intermediate } \\
\text { care unit }\end{array}$ & $\begin{array}{l}\text { The nursing } \\
\text { handoff report } \\
\text { was modified } \\
\text { from a recorded } \\
\text { report (following } \\
\text { SBAR format) to } \\
\text { a blend of both } \\
\text { recorded } \\
\text { (condensed } \\
\text { SBAR format) } \\
\text { and bedside } \\
\text { components. } \\
\text { Baseline, one } \\
\text { month., pre and } \\
\text { postimplementati } \\
\text { on data were } \\
\text { recorded. A } \\
\text { training video } \\
\text { was made for the } \\
\text { nurses. }\end{array}$ & $\begin{array}{l}\text { A mixed- } \\
\text { method, pretest- } \\
\text { posttest } \\
\text { evaluative } \\
\text { approach } \\
\text { involving quasi- } \\
\text { experimental } \\
\text { and } \\
\text { ethnographic } \\
\text { elements was } \\
\text { used. Patient } \\
\text { perceptions were } \\
\text { obtained using } \\
\text { ethnographic } \\
\text { interviewing. } \\
\text { Staff perceptions } \\
\text { of patient } \\
\text { involvement } \\
\text { were obtained } \\
\text { through } \\
\text { questions rated } \\
\text { on a seven-point } \\
\text { Likert scale and } \\
\text { ethnographic } \\
\text { interviewing. }\end{array}$ & $\begin{array}{l}\text { Bedside report } \\
\text { was implemented } \\
\text { on a labor and } \\
\text { delivery unit to } \\
\text { evaluate if it } \\
\text { improved patient } \\
\text { satisfaction and } \\
\text { safety. }\end{array}$ \\
\hline $\begin{array}{l}\text { After six weeks, } \\
\text { the most } \\
\text { significant } \\
\text { improvements } \\
\text { were in } \\
\text { understanding of } \\
\text { the goals for the } \\
\text { day: nurses' } \\
\text { scores improved } \\
(\mathrm{P}=.001) \text { from } \\
3.9 \text { (SD } 1.02) \text { to } \\
4.8 \\
\text { (SD 0.39) and } \\
\text { physicians' scores } \\
\text { improved (P = } \\
.03) \\
\text { from } 4.6 \text { (SD } \\
0.67) \text { to } 4.9 \text { (SD }\end{array}$ & $\begin{array}{l}\text { RNs' } \\
\text { perception of } \\
\text { bedside report } \\
\text { was positive: } \\
\text { noting they } \\
\text { could make } \\
\text { sense of their } \\
\text { patients' } \\
\text { conditions } \\
\text { sooner, could } \\
\text { prioritize } \\
\text { their day } \\
\text { around } \\
\text { patient needs } \\
\text { patient } \\
\text { satisfaction in } \\
\text { nursing } \\
\text { communicatio }\end{array}$ & $\begin{array}{l}\text { Increased patient } \\
\text { satisfaction and } \\
\text { nurse perception } \\
\text { of accountability } \\
\text { and patient } \\
\text { involvement but } \\
\text { reduced nurse } \\
\text { perceptions of } \\
\text { efficiency and } \\
\text { effectiveness of } \\
\text { the report. Patient } \\
\text { falls ( } 35 \% \\
\text { reduction rate) at } \\
\text { shift change and } \\
\text { medication errors } \\
\text { (50\% reduction } \\
\text { rate) were } \\
\text { reduced. Nurse }\end{array}$ & $\begin{array}{l}\text { Results } \\
\text { indicated that } \\
\text { patients } \\
\text { preferred the } \\
\text { bedside } \\
\text { handover } \\
\text { method over the } \\
\text { traditional } \\
\text { closed-door } \\
\text { office handover } \\
\text { approach. The } \\
\text { key differences } \\
\text { (as defined by } \\
\text { patients) were } \\
\text { that the bedside } \\
\text { handover } \\
\text { process } \\
\text { incorporates }\end{array}$ & $\begin{array}{l}\text { Bedside report } \\
\text { was implemented } \\
\text { on a labor and } \\
\text { delivery unit to } \\
\text { evaluate if its } \\
\text { improved patient } \\
\text { satisfaction and } \\
\text { safety as well as } \\
\text { teamwork among } \\
\text { the nurses } \\
\text { practicing it and } \\
\text { was found to be } \\
\text { successful in all } \\
\text { aspects }\end{array}$ \\
\hline
\end{tabular}




\begin{tabular}{|c|c|c|c|c|}
\hline $\begin{array}{l}0.32 \text { ). Scores } \\
\text { remained } \\
\text { high nine months } \\
\text { later in both } \\
\text { groups: } 4.4 \text { (SD } \\
0.51 \text { ) for } \\
\text { nurses and } 4.6 \\
\text { (SD 0.61) for } \\
\text { physicians. } \\
\text { other physicians } \\
\text { and nurses also } \\
\text { reported } \\
\text { significant } \\
\text { improvement in } \\
\text { communication } \\
\text { with each other: } \\
\text { nurses' } \\
\text { scores improved } \\
\text { (P=.03) from } 3.6 \\
\text { (SD 0.87) to } 4.3 \\
\text { (SD } \\
0.87 \text { ), and } \\
\text { physicians' scores } \\
\text { improved (P = } \\
.01) \text { from } \\
3.4 \text { (SD 0.90) to } \\
4.7 \text { (SD 0.48). } \\
\text { Communication } \\
\text { scores } \\
\text { remained high } \\
\text { nine months after } \\
\text { the worksheet was } \\
\text { implemented (4.2 } \\
\text { for nurses and } 4.4 \\
\text { for physicians) }\end{array}$ & $\begin{array}{l}n \text { increased } \\
\text { from } 75 \% \text { to } \\
87.6 \%\end{array}$ & $\begin{array}{l}\text { overtime } \\
\text { remained } \\
\text { unchanged. }\end{array}$ & $\begin{array}{l}\text { social aspects } \\
\text { for the patient. } \\
\text { Patients could } \\
\text { know who is } \\
\text { looking after } \\
\text { them, and } \\
\text { patients are } \\
\text { included in } \\
\text { discussions } \\
\text { related to their } \\
\text { care. }\end{array}$ & \\
\hline $\begin{array}{l}\text { The authors } \\
\text { agreed that the } \\
\text { results of this } \\
\text { study supported } \\
\text { the use of simple } \\
\text { goals worksheet } \\
\text { to improve } \\
\text { communication } \\
\text { between nurses } \\
\text { and physicians. }\end{array}$ & $\begin{array}{l}\text { Bedside shift } \\
\text { reports were } \\
\text { associated } \\
\text { with positive } \\
\text { impacts such } \\
\text { as decreased } \\
\text { falls, which in } \\
\text { turn improved } \\
\text { patients' } \\
\text { satisfaction. }\end{array}$ & $\begin{array}{l}\text { A routine } \\
\text { presence of a } \\
\text { registered nurse } \\
\text { promoted patient } \\
\text { safety, as seen by } \\
\text { the declining falls } \\
\text { scores. Patient } \\
\text { certainty of nurse } \\
\text { presence and the } \\
\text { trust in the }\end{array}$ & $\begin{array}{l}\text { The results } \\
\text { demonstrated } \\
\text { that both } \\
\text { patients and } \\
\text { staff perceived } \\
\text { patients to be } \\
\text { more involved } \\
\text { in their care } \\
\text { under the } \\
\text { bedside }\end{array}$ & $\begin{array}{l}\text { The authors } \\
\text { concluded that } \\
\text { bedside shift } \\
\text { reports were } \\
\text { crucial not only } \\
\text { in enhancing } \\
\text { patients' } \\
\text { satisfaction } \\
\text { scores but also on }\end{array}$ \\
\hline
\end{tabular}




\begin{tabular}{|c|c|c|c|c|}
\hline $\begin{array}{l}\text { Nurses perceived } \\
\text { more } \\
\text { improvement in } \\
\text { communication } \\
\text { with the provision } \\
\text { of skills on how to } \\
\text { use the worksheet. }\end{array}$ & & $\begin{array}{l}\text { nursing care } \\
\text { through bedside } \\
\text { shift reports } \\
\text { flourished since } \\
\text { the } \\
\text { implementation } \\
\text { of the BSR } \\
\text { intervention. } \\
\text { They were } \\
\text { evidenced in } \\
\text { increased patient } \\
\text { satisfaction } \\
\text { scores and patient } \\
\text { surveys. }\end{array}$ & $\begin{array}{l}\text { handover } \\
\text { approach. The } \\
\text { literature noted a } \\
\text { recent move } \\
\text { towards } \\
\text { adopting patient- } \\
\text { centered care } \\
\text { approaches in } \\
\text { clinical settings } \\
\text { and the many } \\
\text { benefits } \\
\text { associated with } \\
\text { this style of } \\
\text { care. }\end{array}$ & $\begin{array}{l}\text { improving the } \\
\text { level of safety. }\end{array}$ \\
\hline $\begin{array}{l}\text { One of the main } \\
\text { strengths was that } \\
\text { the worksheet was } \\
\text { designed as a } \\
\text { template } \\
\text { with spaces for } \\
\text { the team to fill in } \\
\text { the plan during } \\
\text { morning rounds, } \\
\text { and thus minimal } \\
\text { amount of time } \\
\text { was required to } \\
\text { fill in the } \\
\text { worksheet. The } \\
\text { worksheet could } \\
\text { easily be modified } \\
\text { and applied to } \\
\text { other units in the } \\
\text { hospital. }\end{array}$ & $\begin{array}{l}\text { A limitation } \\
\text { was that the } \\
\text { evidence- } \\
\text { based design } \\
\text { prevented } \\
\text { generalization } \\
\text { of findings to } \\
\text { other settings; } \\
\text { however, the } \\
\text { knowledge } \\
\text { gained may } \\
\text { be transferred } \\
\text { to other units } \\
\text { or hospitals }\end{array}$ & $\begin{array}{l}\text { A convenience } \\
\text { sample was used, } \\
\text { which could } \\
\text { hinder the } \\
\text { generalizability } \\
\text { of the study. }\end{array}$ & $\begin{array}{l}\text { Study strengths } \\
\text { included a large, } \\
\text { diverse } \\
\text { population and } \\
\text { detailed } \\
\text { assessments of } \\
\text { patient } \\
\text { experiences of } \\
\text { communication } \\
\text { within various } \\
\text { types of } \\
\text { healthcare. }\end{array}$ & $\begin{array}{l}\text { There was a } \\
\text { potential non- } \\
\text { response bias, } \\
\text { and the findings } \\
\text { may not be } \\
\text { generalized. }\end{array}$ \\
\hline $\begin{array}{l}\text { Attaining } \\
\text { education on how } \\
\text { to use the reports } \\
\text { was helpful to the } \\
\text { physicians, not } \\
\text { only in improving } \\
\text { their } \\
\text { communication } \\
\text { but also on how } \\
\text { they were able to } \\
\text { administer } \\
\text { treatment. The } \\
\text { result was an }\end{array}$ & $\begin{array}{l}\text { Earlier } \\
\text { identification } \\
\text { and } \\
\text { correction of } \\
\text { potential } \\
\text { errors during } \\
\text { BSR may } \\
\text { have } \\
\text { improved the } \\
\text { quality of } \\
\text { patient care. } \\
\text { Nurses } \\
\text { reported an }\end{array}$ & $\begin{array}{l}\text { Through bedside } \\
\text { shift reports as } \\
\text { well as the } \\
\text { elimination of } \\
\text { chances of } \\
\text { skipping by the } \\
\text { oncoming nurses } \\
\text { improved } \\
\text { patients' } \\
\text { satisfaction. } \\
\text { Nurses could } \\
\text { assess the } \\
\text { patients' }\end{array}$ & $\begin{array}{l}\text { This study } \\
\text { proved that } \\
\text { implementing } \\
\text { bedside } \\
\text { handover } \\
\text { resulted in a } \\
\text { patient-centered } \\
\text { approach. This } \\
\text { study generated } \\
\text { further } \\
\text { knowledge } \\
\text { about rural } \\
\text { nursing and }\end{array}$ & $\begin{array}{l}\text { Based on the } \\
\text { study, the bedside } \\
\text { shift reports also } \\
\text { helped to } \\
\text { promote nurses' } \\
\text { level of } \\
\text { accountability in } \\
\text { their tasks } \\
\text { besides } \\
\text { improving the } \\
\text { patients' } \\
\text { experience. }\end{array}$ \\
\hline
\end{tabular}




\begin{tabular}{|c|c|c|c|c|}
\hline $\begin{array}{l}\text { improvement in } \\
\text { patients' } \\
\text { satisfaction. }\end{array}$ & $\begin{array}{l}\text { increase in } \\
\text { availability } \\
\text { and degree of } \\
\text { openness to } \\
\text { questions } \\
\text { between } \\
\text { outgoing and } \\
\text { oncoming } \\
\text { nurses, which } \\
\text { has been } \\
\text { associated } \\
\text { with } \\
\text { improved } \\
\text { communicatio } \\
\mathrm{n} \text { and quality } \\
\text { of care. }\end{array}$ & $\begin{array}{l}\text { emotional and } \\
\text { psychological } \\
\text { needs more } \\
\text { easily. }\end{array}$ & $\begin{array}{l}\text { contributed } \\
\text { insight into the } \\
\text { importance of } \\
\text { handover } \\
\text { implementation } \\
\text { method - areas } \\
\text { that are not } \\
\text { widely } \\
\text { documented in } \\
\text { the existing } \\
\text { literature. }\end{array}$ & \\
\hline $\begin{array}{l}\text { Lincoln \& Nicole } \\
\text { (2016) }\end{array}$ & $\begin{array}{l}\text { Cairns, } \\
\text { Dudjak, } \\
\text { Hoffman, \& } \\
\text { Lorenz } \\
(2013)\end{array}$ & $\begin{array}{l}\text { Evans, } \\
\text { Grunawait, } \\
\text { McClish, Wood, } \\
\text { \& Frise (2012) }\end{array}$ & $\begin{array}{l}\text { Johnstone, M. J., } \\
\text { Hutchinson, A. } \\
\text { M., Rawson, H., } \\
\text { \& Redley, B. } \\
\text { (2016) }\end{array}$ & $\begin{array}{l}\text { Usher, Cronin \& } \\
\text { York (2018) }\end{array}$ \\
\hline Pilot Study & $\begin{array}{l}\text { Non- } \\
\text { experimental }\end{array}$ & $\begin{array}{l}\text { Non- } \\
\text { experimental }\end{array}$ & $\begin{array}{l}\text { Qualitative } \\
\text { descriptive } \\
\text { approach }\end{array}$ & $\begin{array}{l}\text { Randomized } \\
\text { Controlled Trial }\end{array}$ \\
\hline Level I & Level IV & Level IV & Level I & Level II \\
\hline 1B & $1 \mathrm{C}$ & $2 \mathrm{~A}$ & 1B & $1 \mathrm{~A}$ \\
\hline $\begin{array}{l}\text { The purpose of } \\
\text { this evidence- } \\
\text { based project was } \\
\text { to increase the } \\
\text { accuracy of } \\
\text { communication } \\
\text { during nursing } \\
\text { handoff by } \\
\text { implementing a } \\
\text { structured } \\
\text { approach to } \\
\text { bedside handoff I- } \\
\text { PASS with } \\
\text { SAFETY to } \\
\text { enhance patient } \\
\text { safety and } \\
\text { satisfaction. }\end{array}$ & $\begin{array}{l}\text { To promote a } \\
\text { decrease in } \\
\text { near misses, } \\
\text { incomplete } \\
\text { information, } \\
\text { and zero } \\
\text { sentinel } \\
\text { events } \\
\text { through } \\
\text { involving the } \\
\text { patient in } \\
\text { shift handoff. }\end{array}$ & $\begin{array}{l}\text { To evaluate the } \\
\text { effect of bedside } \\
\text { handoff reports } \\
\text { on a nurse to } \\
\text { nurse } \\
\text { communication } \\
\text { and collaboration. }\end{array}$ & $\begin{array}{l}\text { To explore and } \\
\text { describe the } \\
\text { strategies nurses } \\
\text { used to facilitate } \\
\text { engagement } \\
\text { with families of } \\
\text { older immigrant } \\
\text { NESB patients } \\
\text { hospitalized for } \\
\text { EOL care }\end{array}$ & $\begin{array}{l}\text { Evaluating the } \\
\text { Influence of a } \\
\text { Standardized } \\
\text { Bedside Handoff } \\
\text { Process in a } \\
\text { Medical-Surgical } \\
\text { Unit }\end{array}$ \\
\hline $\begin{array}{l}\text { All RN staff } \\
\text { received video }\end{array}$ & $\begin{array}{l}\text { The value of } \\
\text { bedside report }\end{array}$ & Sample $(n=100)$ & $\begin{array}{l}\text { A purposeful } \\
\text { sample of } 22\end{array}$ & $\begin{array}{l}\text { The Project Lead } \\
\text { performed } 15\end{array}$ \\
\hline
\end{tabular}




\begin{tabular}{|c|c|c|c|c|}
\hline $\begin{array}{l}\text { training and } \\
\text { attended staff } \\
\text { meetings where } \\
\text { evidence from the } \\
\text { current literature } \\
\text { was reviewed. } \\
\text { Implementation } \\
\text { involved utilizing } \\
\text { I-PASS, a } \\
\text { standardized } \\
\text { verbal handoff } \\
\text { format with a } \\
\text { written tool, and } \\
\text { SAFETY, an } \\
\text { innovative } \\
\text { bedside handoff } \\
\text { acronym, was } \\
\text { created at this } \\
\text { hospital to } \\
\text { organize bedside } \\
\text { handoff into a } \\
\text { consistent } \\
\text { structure with a } \\
\text { checklist. }\end{array}$ & $\begin{array}{l}\text { was measured } \\
\text { on a } 23 \text {-bed } \\
\text { inpatient unit. }\end{array}$ & & $\begin{array}{l}\text { registered nurses } \\
\text { was recruited } \\
\text { from four } \\
\text { hospitals in } \\
\text { metropolitan } \\
\text { Melbourne and } \\
\text { regional } \\
\text { Victoria. } \\
\text { Inclusion criteria } \\
\text { were holding } \\
\text { current } \\
\text { registration as a } \\
\text { nurse (division } \\
\text { 1); practicing in } \\
\text { a Victorian } \\
\text { hospital; } \\
\text { provided care to } \\
\text { older NESB } \\
\text { immigrant } \\
\text { patients aged } 65 \\
\text { years and older; } \\
\text { admitted to } \\
\text { acute care } \\
\text { services for } \\
\text { EOL care. } \\
\text { Twenty-two } \\
\text { nurses recruited } \\
\text { to the study: } 11 \\
\text { worked in } \\
\text { medical-surgical } \\
\text { wards and } \\
\text { critical care, } \\
\text { eight worked in } \\
\text { acute palliative } \\
\text { care, and three } \\
\text { worked in the } \\
\text { aged care sector. }\end{array}$ & $\begin{array}{l}\text { random } \\
\text { observations } \\
\text { before the } \\
\text { implementation } \\
\text { of the project }\end{array}$ \\
\hline $\begin{array}{l}\text { Compliance was } \\
\text { assessed using a } \\
\text { standardized audit } \\
\text { tool. Nurses were } \\
\text { surveyed for their } \\
\text { perceptions of the } \\
\text { new processes six } \\
\text { months } \\
\text { postimplementatio }\end{array}$ & $\begin{array}{l}\text { Indicators, } \\
\text { including } \\
\text { end-of-shift } \\
\text { overtime, call } \\
\text { light usage, } \\
\text { nurse } \\
\text { perceptions, } \\
\text { and the } \\
\text { change in the }\end{array}$ & $\begin{array}{l}\text { A pre- } \\
\text { implementation } \\
\text { survey was } \\
\text { distributed } \\
\text { among the nurses } \\
\text { to assess their } \\
\text { perception and } \\
\text { satisfaction with } \\
\text { the current nurse }\end{array}$ & $\begin{array}{l}\text { The findings } \\
\text { presented in this } \\
\text { article derive } \\
\text { from a larger } \\
\text { study } \\
\text { investigating the } \\
\text { decision-making } \\
\text { strategies used } \\
\text { by registered }\end{array}$ & $\begin{array}{l}\text { An evidence- } \\
\text { based project was } \\
\text { performed in a } \\
\text { medical-surgical } \\
\text { unit and consisted } \\
\text { of development, } \\
\text { implementation, } \\
\text { and evaluation of } \\
\text { a standardized }\end{array}$ \\
\hline
\end{tabular}




\begin{tabular}{|c|c|c|c|c|}
\hline $\begin{array}{l}\text { n. Selected } \\
\text { questions from the } \\
\text { Hospital } \\
\text { Consumer } \\
\text { Assessment of } \\
\text { Healthcare } \\
\text { Providers and } \\
\text { Systems } \\
\text { (HCAHPS) were } \\
\text { evaluated }\end{array}$ & $\begin{array}{l}\text { process, } \\
\text { impacted } \\
\text { patient } \\
\text { satisfaction. }\end{array}$ & $\begin{array}{l}\text { shift handoff } \\
\text { process }\end{array}$ & $\begin{array}{l}\text { nurses when } \\
\text { caring for older } \\
\text { immigrants of } \\
\text { NESB } \\
\text { hospitalized for } \\
\text { EOL care, but } \\
\text { which could not } \\
\text { be considered } \\
\text { within the scope } \\
\text { of the original } \\
\text { report }\end{array}$ & $\begin{array}{l}\text { bedside handoff. } \\
\text { The project } \\
\text { included } \\
\text { surveying nurses, } \\
\text { a web-based } \\
\text { educational } \\
\text { program, and } \\
\text { observations } \\
\text { using the SBAR } \\
\text { (T) competency } \\
\text { checklist tool. } \\
\text { Data were } \\
\text { analyzed for } \\
\text { trends. }\end{array}$ \\
\hline $\begin{array}{l}\text { Based on unit- } \\
\text { level HCAHPS } \\
\text { data, there was a } \\
50 \% \text { increase in } \\
\text { the question } \\
\text { "Staff Does } \\
\text { Everything to } \\
\text { Help with Pain," a } \\
16.7 \% \text { increase in } \\
\text { the "Nurses listen } \\
\text { carefully to you" } \\
\text { question, an } 8.3 \% \\
\text { increase in the } \\
\text { "Nurses, explain } \\
\text { things in a way } \\
\text { you understand" } \\
\text { question and an } \\
8.3 \% \text { increase in } \\
\text { patients' "Rating } \\
\text { the hospital a nine } \\
\text { or ten" during the } \\
\text { three-month pilot } \\
\text { period. The fall } \\
\text { rate, although } \\
\text { variable, } \\
\text { decreased } 51 \% \\
\text { from } 6.11 \text { per } \\
1,000 \text { patient days } \\
\text { pre-pilot to } 2.97 \\
\text { per } 1,000 \text { patient } \\
\text { days over six } \\
\text { months. }\end{array}$ & $\begin{array}{l}\text { Results } \\
\text { indicated } \\
\text { over- time } \\
\text { decreases or } \\
\text { decreases } \\
\text { insignificantl } \\
\text { y after the } \\
\text { implementati } \\
\text { on of bedside } \\
\text { handoff } \\
\text { reports. The } \\
\text { nursing over } \\
\text { shift time was } \\
\text { reduced by } 10 \\
\text { minutes per } \\
\text { day. Evidence } \\
\text { strongly } \\
\text { supported that } \\
\text { the bedside } \\
\text { shift report } \\
\text { increased } \\
\text { nurse } \\
\text { satisfaction. }\end{array}$ & $\begin{array}{l}\text { Upon } \\
\text { implementation } \\
\text { of the bedside } \\
\text { shift reports, the } \\
\text { survey indicated } \\
\text { increased staff } \\
\text { satisfaction, } \\
\text { prioritization, and } \\
\text { decreased time } \\
\text { spent giving and } \\
\text { receiving a } \\
\text { report. } \\
\text { Additionally, } \\
\text { improved } \\
\text { communication } \\
\text { indicated } \\
\text { increased } \\
\text { collaboration } \\
\text { among nurses. }\end{array}$ & $\begin{array}{l}\text { Data suggested } \\
\text { that, in general, } \\
\text { the participants } \\
\text { used four key } \\
\text { strategies to } \\
\text { actively engage } \\
\text { families of } \\
\text { NESB } \\
\text { backgrounds in } \\
\text { EOL care, } \\
\text { notably: } \\
\text { "listening to and } \\
\text { understanding } \\
\text { the family," } \\
\text { "encouraging } \\
\text { family members } \\
\text { to speak first," } \\
\text { "ascertaining the } \\
\text { family's } \\
\text { decision-making } \\
\text { model," and } \\
\text { "dealing with } \\
\text { angst," with the } \\
\text { latter } \\
\text { encompassing } \\
\text { the additional } \\
\text { sub-strategies of } \\
\text { "redressing } \\
\text { naive views } \\
\text { about the dying } \\
\text { process" and } \\
\text { "dealing with }\end{array}$ & $\begin{array}{l}\text { Independent } \mathrm{t} \\
\text { tests were used to } \\
\text { compare the } \\
\text { results of the } \\
\text { MSR scale pre } \\
\text { and } \\
\text { postimplementati } \\
\text { on results } \\
\text { revealing a } \\
\text { statistically } \\
\text { significant } \\
\text { improvement in } \\
\text { the nurses' } \\
\text { overall } \\
\text { perceptions of } \\
\text { shift report } \\
\text { preimplementatio } \\
\mathrm{n}(\mathrm{M}=7.31, \mathrm{SD} \\
=1.18) \text { versus } \\
\text { postimplementati } \\
\text { on }(\mathrm{M}=6.60, \mathrm{SD} \\
=1.44) \text { of the } \\
\text { project }(\mathrm{t}=2.05, \\
\text { df }=55, \mathrm{p}, .05) . \\
\text { In addition, there } \\
\text { was significant } \\
\text { improvement in } \\
\text { the nurses' } \\
\text { perceptions of } \\
\text { standardized } \\
\text { bedside handoff } \\
\text { versus the usual }\end{array}$ \\
\hline
\end{tabular}




\begin{tabular}{|c|c|c|c|c|}
\hline & & & $\begin{array}{l}\text { intergenerational } \\
\text { differences in } \\
\text { values and } \\
\text { beliefs about } \\
\text { EOL decision- } \\
\text { making and care } \\
\text { EOL care, but } \\
\text { which could not } \\
\text { be considered } \\
\text { within the scope } \\
\text { of the original } \\
\text { report. Bedside } \\
\text { shift report was } \\
\text { identified as an } \\
\text { essential tool in } \\
\text { ensuring that the } \\
\text { families felt } \\
\text { their loved ones } \\
\text { were completely } \\
\text { taken care of. }\end{array}$ & $\begin{array}{l}\text { hand-off pre }(\mathrm{M} \\
=19.34, \mathrm{SD}= \\
3.65) \text { versus post } \\
\text { implementation } \\
(\mathrm{M}=17.44, \mathrm{SD}= \\
3.34) \text { of the } \\
\text { project }(\mathrm{t}=2.05, \\
\mathrm{df}=53.56, \mathrm{p}, \\
.05) .\end{array}$ \\
\hline $\begin{array}{l}\text { The authors } \\
\text { agreed that while } \\
\text { pilot data showed } \\
\text { global } \\
\text { improvements in } \\
\text { the unit, } \\
\text { researchers } \\
\text { concluded that it } \\
\text { is important to } \\
\text { focus } \\
\text { postimplementatio } \\
\text { n on the } \\
\text { sustainability and } \\
\text { hardwiring of } \\
\text { those processes } \\
\text { that would further } \\
\text { improve patient } \\
\text { experience and } \\
\text { satisfaction on the } \\
\text { unit. }\end{array}$ & $\begin{array}{l}\text { The authors } \\
\text { noted some of } \\
\text { the } \\
\text { advantages } \\
\text { associated } \\
\text { with bedside } \\
\text { shift reports, } \\
\text { such as } \\
\text { improved } \\
\text { report } \\
\text { efficiency, } \\
\text { teamwork, } \\
\text { nursing } \\
\text { accountability } \\
\text {, and report } \\
\text { accuracy; } \\
\text { enhanced } \\
\text { individual } \\
\text { patient care } \\
\text { and } \\
\text { documentatio } \\
\text { n practices; } \\
\text { satisfaction } \\
\text { with patients } \\
\text { being } \\
\text { involved; }\end{array}$ & $\begin{array}{l}\text { All the authors } \\
\text { agreed that } \\
\text { bedside shift } \\
\text { reports resulted in } \\
\text { increased staff } \\
\text { satisfaction, } \\
\text { prioritization, and } \\
\text { decreased time } \\
\text { spent giving and } \\
\text { receiving a } \\
\text { report. }\end{array}$ & $\begin{array}{l}\text { The authors } \\
\text { appreciated } \\
\text { several } \\
\text { strategies, } \\
\text { including the } \\
\text { role of bedside } \\
\text { shift reports, in } \\
\text { making the } \\
\text { patients feeling } \\
\text { involved in the } \\
\text { treatment } \\
\text { process. }\end{array}$ & $\begin{array}{l}\text { The authors } \\
\text { agreed that the } \\
\text { project } \\
\text { demonstrated an } \\
\text { improvement in } \\
\text { the nurses' } \\
\text { perceptions of } \\
\text { shift report. The } \\
\text { shift report } \\
\text { subscale } \\
\text { suggested that } \\
\text { nurses on the unit } \\
\text { felt better } \\
\text { prepared to care } \\
\text { for their patients } \\
\text { and perform their } \\
\text { job following the } \\
\text { implementation } \\
\text { of bedside shift } \\
\text { reports. }\end{array}$ \\
\hline
\end{tabular}




\begin{tabular}{|c|c|c|c|c|}
\hline & $\begin{array}{l}\text { visualizing } \\
\text { patients and } \\
\text { the ability to } \\
\text { prioritize } \\
\text { care, and } \\
\text { improved } \\
\text { discharge or } \\
\text { transition of } \\
\text { care. }\end{array}$ & & & \\
\hline $\begin{array}{l}\text { The success of the } \\
\text { pilot led to the } \\
\text { hospital-wide } \\
\text { implementation of } \\
\text { the standardized } \\
\text { approach of } \\
\text { integrating IPASS } \\
\text { and SAFETY for } \\
\text { nursing bedside } \\
\text { handoff and } \\
\text { verbal reports. }\end{array}$ & $\begin{array}{l}\text { Only three } \\
\text { studies were } \\
\text { found to have } \\
\text { a sample size } \\
\text { greater than } \\
100 \text { patients } \\
\text { that directly } \\
\text { measured the } \\
\text { patient } \\
\text { experience } \\
\text { with nurse } \\
\text { bedside shift } \\
\text { report by } \\
\text { distributing } \\
\text { surveys to } \\
\text { patients and } \\
\text { determining } \\
\text { that the } \\
\text { overall } \\
\text { patient } \\
\text { perception of } \\
\text { the process } \\
\text { was positive }\end{array}$ & $\begin{array}{l}\text { One of the main } \\
\text { strengths of the } \\
\text { project was the } \\
\text { large sample } \\
\text { used, thereby } \\
\text { avoiding biases } \\
\text { of the } \\
\text { information } \\
\text { obtained. }\end{array}$ & $\begin{array}{l}\text { A limitation of } \\
\text { the component } \\
\text { of the study } \\
\text { reported was } \\
\text { that it has had as } \\
\text { its focus the } \\
\text { views and } \\
\text { accounts only of } \\
\text { nurses involved } \\
\text { in the EOL care } \\
\text { of older NESB } \\
\text { immigrant } \\
\text { patients and } \\
\text { their families. }\end{array}$ & $\begin{array}{l}\text { Visible } \\
\text { leadership during } \\
\text { a shift change } \\
\text { was a key } \\
\text { strength of this } \\
\text { project. Unit- } \\
\text { based nursing } \\
\text { leadership was } \\
\text { available } 24 \\
\text { hours per day to } \\
\text { address any } \\
\text { concerns during } \\
\text { the trial of the } \\
\text { new process. } \\
\text { Unit-based nurse } \\
\text { leaders } \\
\text { communicated } \\
\text { the importance of } \\
\text { an effective } \\
\text { bedside handoff } \\
\text { to nurses } \\
\text { regularly during } \\
\text { interdisciplinary } \\
\text { rounds, staff } \\
\text { meetings, and } \\
\text { shift starters. } \\
\text { Another key } \\
\text { strength of the } \\
\text { project was the } \\
\text { early } \\
\text { identification of } \\
\text { nurses who } \\
\text { served as change } \\
\text { champions on } \\
\text { various shifts. }\end{array}$ \\
\hline $\begin{array}{l}\text { Apart from an } \\
\text { increase in nurse }\end{array}$ & $\begin{array}{l}\text { Handoffs are } \\
\text { dependent on }\end{array}$ & $\begin{array}{l}\text { Increased staff } \\
\text { satisfaction, }\end{array}$ & $\begin{array}{l}\text { Nurses, who are } \\
\text { at the forefront }\end{array}$ & $\begin{array}{l}\text { The study } \\
\text { identified the role }\end{array}$ \\
\hline
\end{tabular}




\begin{tabular}{|c|c|c|c|c|}
\hline $\begin{array}{l}\text { communication } \\
\text { and patient } \\
\text { experience, the } \\
\text { study also } \\
\text { indicated the } \\
\text { positive impact of } \\
\text { bedside shift } \\
\text { reports on } \\
\text { declining adverse } \\
\text { events. }\end{array}$ & $\begin{array}{l}\text { the } \\
\text { communicatio } \\
\mathrm{n} \text { style and } \\
\text { skill of } \\
\text { healthcare } \\
\text { providers in } \\
\text { addition to } \\
\text { the } \\
\text { experience } \\
\text { and } \\
\text { knowledge of } \\
\text { both } \\
\text { individuals } \\
\text { and often } \\
\text { result in } \\
\text { process } \\
\text { inconsistencie } \\
\text { s. } \\
\text { Additionally, } \\
\text { the reports } \\
\text { help to } \\
\text { minimize } \\
\text { sentinel } \\
\text { events. }\end{array}$ & $\begin{array}{l}\text { prioritization, and } \\
\text { decreased time } \\
\text { spent giving and } \\
\text { receiving report } \\
\text { did not eliminate } \\
\text { the chances of } \\
\text { skipping a patient } \\
\text { by the oncoming } \\
\text { nurse but } \\
\text { improved nurse } \\
\text { to nurse } \\
\text { communication } \\
\text { and collaboration. } \\
\text { These aspects } \\
\text { positively } \\
\text { affected the } \\
\text { delivery of } \\
\text { treatment care, } \\
\text { thereby } \\
\text { improving patient } \\
\text { satisfaction. }\end{array}$ & $\begin{array}{l}\text { of caring for } \\
\text { patients at the } \\
\text { hospitals, can } \\
\text { make a profound } \\
\text { difference in } \\
\text { how patients and } \\
\text { their families } \\
\text { experience the } \\
\text { treatment } \\
\text { process. Many } \\
\text { of the strategies } \\
\text { stated in this } \\
\text { study could be } \\
\text { implemented } \\
\text { effectively by } \\
\text { deploying } \\
\text { bedside reports. } \\
\text { Aspects such as } \\
\text { a deeper } \\
\text { understanding of } \\
\text { the patients' } \\
\text { needs and } \\
\text { emotional } \\
\text { support were } \\
\text { mainly possible } \\
\text { through the } \\
\text { reports. }\end{array}$ & $\begin{array}{l}\text { of BSR in } \\
\text { improving patient } \\
\text { satisfaction and } \\
\text { in helping the } \\
\text { care providers } \\
\text { attain the targeted } \\
\text { outcomes. }\end{array}$ \\
\hline
\end{tabular}




\section{Appendix B}

SWOT Analysis

\begin{tabular}{|c|c|}
\hline Internal Forces (Project) & $\begin{array}{l}\text { External Forces (Organization or } \\
\text { Environment) }\end{array}$ \\
\hline $\begin{array}{l}\text { Strength } \\
\text { - } \text { Knowledgeable and dedicated } \\
\text { physicians/nurses } \\
\text { - } \text { Operational efficiency/productivity } \\
\text { - } \text { Availability of technology } \\
\text { - } \text { An abundance of resources within the } \\
\text { organization } \\
\text { - } \text { Best practices (e.g., EBP) }\end{array}$ & $\begin{array}{l}\text { Opportunities } \\
\text { - } \text { Improve financial viability } \\
\text { - Potential to be a Top } 100 \text { Hospital } \\
\text { - } \text { Professional development of } \\
\text { physicians/nurses } \\
\text { - } \text { Improve patient flow and volume }\end{array}$ \\
\hline $\begin{array}{l}\text { Weaknesses } \\
\text { - } \begin{array}{l}\multicolumn{1}{c}{\text { Increase the turnover of nurses and }} \\
\text { physicians }\end{array} \\
\text { - Lack of experience from nurses and } \\
\text { physicians } \\
\text { - Staff re-training } \\
\text { - Time constraint }\end{array}$ & $\begin{array}{l}\text { Threats } \\
\text { - High competition from other } \\
\text { organizations } \\
\text { - Maintaining clinical excellence and } \\
\text { quality care } \\
\text { - Other hospitals offering higher rates of } \\
\text { pay for physicians and nurses }\end{array}$ \\
\hline
\end{tabular}




\section{Appendix C}

\section{EPRC Permission Letter}

University of St. Augustine for Health Sciences

Doctor of Nursing Practice Program

Evidence-Based Practice Review Council

1 University Blvd.

St. Augustine, FL 32086

$2 / 26 / 20$

Dear Victoria Ogundeko,

Your proposal titled [For hospitalized adult patients $(\mathrm{P})$, does the implementation of nursing

bedside handoff report (I) compared to desk handoff report improve patient satisfaction scores

(O) in 2 months (T)?] has been reviewed by the University of St. Augustine for Health Sciences

Doctor of Nursing Practice Evidence-Based Practice Review Council (EPRC) and determined to: meet the requirements for research as defined in the Federal Register. You must adjust the proposal to reflect the DNP program requirements and resubmit for additional review. Work closely with your faculty member during this process.

_X_ not meet the requirements for research as defined in the Federal Register. Your proposal reflects an evidence-based practice change project. The proposal must be implemented as submitted (changes are not permitted). You may proceed to obtain approvals from the facility where the project will be implemented. Implementation may not begin until you are notified in writing by faculty that you may implement the project.

Questions regarding the USAHS approval process should be addressed to Dr. Douglas Turner at DTurner@usa.edu. Questions regarding the facility approval process should be addressed to course faculty.

Sincerely,

\section{Douglas Turner}

Douglas M Turner, PhD, DNP, RN, CNE, NE-BC, NEA-BC 


\section{Sherman Oaks Hospital}

From Dr. EM Garcia \& Prof. Roland Santos

4929 Van Nuys Blvd.

Sherman Caks, CA 91403

Ensail: smeanciavo orimehsalitheses com

[5amins2. sximehealtheare cnm

Date: February 04, 2020

Institutional Review Boord

University of St. Aupustine for Health Sciences

700 Windy Point $\mathrm{Dr}$

Sien Mareos CA 92050

Dear USAIIS IRB,

\section{Permission Letter}

Thes is to inform you that Vietoria Ogundeko has been granted permission to conduct an evidence-based, quality impeovement projest at Shermin Oaks Hospital based on the evidence. based, quality improvement project proposal "Improving patient satisfaction seore through bedside shift report." This project is to be coedbeted acopoding to the ethical sandieds applicable to Shemsan Oaks Hospital and in deliberation with the facility Internal Review Beard (IRB) specification for evidence-based, quality improvement project.

The IRB will be informed prompely of any harm towards any participants of the project as an result of that individual participation in the project. The agproval letter is valid for one year from the start date of project. The outcome of your evidence-based, gaality improvement project is to be sharned with other members of bealthcare team at Sherman Oaks Hospital and a copy of the writen manuserigt at the facility for future reference.

For further infocmation please do not hesitate to coecact De. Garcia \& Prof. Sunocs at 805-5588560 and $818-653-0681$ respectively

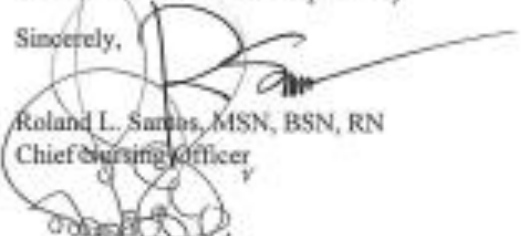

EM V Garci, FW, DNP, DHEd, MSN, MBA, MAEd, APRN, NP-C, CNOR, CSSM,

FACUAC, FIXN

Administrater

$$
\begin{aligned}
& 4920 \text { Van Nays fitud Sherman Oaks, CA 91405 } \\
& \text { Phose: (818) } 981-7 \mathrm{II} \\
& \text { Saviac Hesphak Savieg Lives. Saving lobs. } \\
& \text { A Alenter of Pruve Hestibiove }
\end{aligned}
$$




\section{Appendix D}

Project Budget

\begin{tabular}{|l|l|l|l|}
\hline EXPENSES & & REVENUE & \\
\hline Direct & $\$ 120$ & Billing & $\$ 130$ \\
\hline Salary and benefits & $\$ 0$ & Grants & $\$ 40$ \\
\hline Supplies & $\$ 80$ & Institutional budget support & $\$ 300$ \\
\hline Services & $\$ 10$ & & \\
\hline Statistician & $\$ 500$ & & \\
\hline Stationery & $\$ 20$ & & \\
\hline Transportation & $\$ 50$ & & \\
\hline Indirect & $\$ 60$ & & \\
\hline Overhead (electricity, etc.) & $\$ 10$ & & \\
\hline Total Expenses & & & \\
\hline Net Balance $=\$ 380$ & $\$ 850$ & Total Revenue & \\
\hline
\end{tabular}




\section{Appendix E}

Schedule

\begin{tabular}{|l|c|}
\hline \multicolumn{1}{|c|}{ TASK } & DATE \\
\hline $\begin{array}{l}\text { Nursing EBP project review council at } \\
\text { USAHS approval }\end{array}$ & $02 / 30 / 20$ \\
\hline Approval letter from the facility & $03 / 30 / 19$ \\
\hline Meeting with key stakeholders & $04 / 03 / 20$ \\
\hline Project Design & $04 / 17 / 20$ \\
\hline Structure and conduct staff training & $05 / 12 / / 20-06 / 12 / 20$ \\
\hline Implementation and data collection & $06 / 14 / 20-07 / 14 / 20$ \\
\hline Data analysis and dissemination of results & $07 / 16 / 20-08 / 14 / 20$ \\
\hline
\end{tabular}




\section{Appendix F}

\section{In-Patient Assessment of Healthcare [I-PAHC] Survey}

\begin{tabular}{|c|c|c|c|c|}
\hline \multirow{2}{*}{ 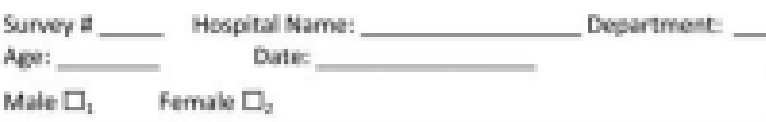 } & \multicolumn{3}{|c|}{ Ward: } & \multirow[b]{2}{*}{ Always } \\
\hline & Never & Sometimes & \multirow{2}{*}{ Usually } & \\
\hline $\begin{array}{l}\text { 1. During this hospital stay, how often did furses treat you with } \\
\text { courtesy and respect? }\end{array}$ & , & , 口 & & 口 \\
\hline $\begin{array}{l}\text { 2. Durhe this hospital stay, how often did curser listen carefully to } \\
\text { you? }\end{array}$ & , & ${ }_{x} \square$ & 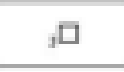 & מג \\
\hline $\begin{array}{l}\text { 3. During this hospital says how often did nunser eaplain things in a } \\
\text { way you could understand? }\end{array}$ & D & 只 & , & D \\
\hline $\begin{array}{l}\text { 4. During this honpital way, how often did doctoryhealth afficen treat } \\
\text { you wh courtey and respect? }\end{array}$ & 口 & ביב & , 口 & $\boldsymbol{D}$ \\
\hline 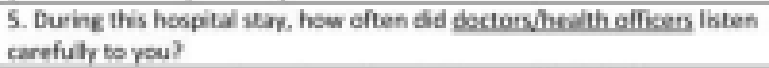 & 口只 & , 口 & , 口 & D \\
\hline $\begin{array}{l}\text { 6. Durne this hospital stay, how often did dectorsihedith officers } \\
\text { explain things in a way pou could understand? }\end{array}$ & 口ם & ${ }_{x} \square$ & , 口 & D \\
\hline 7. I could distinguish between doctors/health oticers and nurses. & Q & 口 & 므 & D \\
\hline $\begin{array}{l}\text { 8. During this hospital atry, how often was the room you were sleeping } \\
\text { in kept clean? }\end{array}$ & 口 & ${ }_{3}$ 口 & , 口 & D \\
\hline $\begin{array}{l}\text { 9. Durine this hospital star, how eften was the area around pou quet } \\
\text { at niqht? }\end{array}$ & 口 & ${ }_{3} \square$ & 므 & D \\
\hline $\begin{array}{l}\text { 10. During this hospical stay, how often did statt make sure you have } \\
\text { etough gersonal privacy? }\end{array}$ & प्र & ${ }_{x}$ 口 & , 口 & Dג \\
\hline 11. During this hosplial stay, did you esperience amy pain? & \multicolumn{4}{|c|}{ DYes O No, skip 12513} \\
\hline 12. During this hoiphal stay, how olten was your pain wetl cemtrolled? & ㅁ & 口 & 口 & ב \\
\hline $\begin{array}{l}\text { 13. During this hosphal stay, how oten did statt do everything they } \\
\text { could to hels you with your pain? }\end{array}$ & ב & प्र & בי & D \\
\hline $\begin{array}{l}\text { 14. During this hosplas stay, were you given ary medication thot you } \\
\text { had not taben before? }\end{array}$ & \multicolumn{4}{|c|}{ पY Yes No, Skip 15816} \\
\hline $\begin{array}{l}\text { 15. Before giving vou any new medication, how often did staff tell you } \\
\text { what the medicine eas for? }\end{array}$ & , & a & , & $\infty$ \\
\hline $\begin{array}{l}\text { 16. Aefore giving you any rew medication, how often did staff dencribe } \\
\text { poss ble side effects in a way yoy could understand? }\end{array}$ & , & 口ם & 口 & D \\
\hline $\begin{array}{l}\text { 17. Were you given information in a wiry you could understand what } \\
\text { spmptams ar heakth preblems to losk out for ater you leure the } \\
\text { hosptal? }\end{array}$ & \multicolumn{4}{|c|}{$\nabla \mathrm{No}$} \\
\hline 18. Was is eary to find your wey around the hospital? & \multirow{3}{*}{\multicolumn{4}{|c|}{ 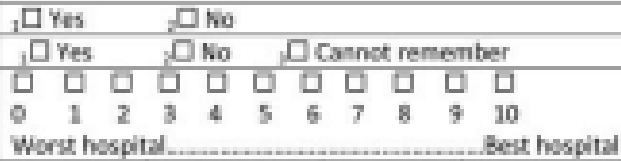 }} \\
\hline 19. Is this your first time being treated at this hosptal? & & & & \\
\hline $\begin{array}{l}\text { 26. On a scale of } 0-1010 \text { being the worn hosptal, } 10 \text { being the best } \\
\text { honpital, how would you rate this houpta? }\end{array}$ & & & & \\
\hline 21. Would you recommend this hospital to vour friends and famly? & $\begin{array}{l}\text { Definisety } \\
\text { no }\end{array}$ & 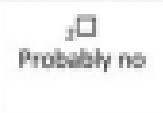 & $\begin{array}{l}\text { probakly } \\
\text { yes }\end{array}$ & 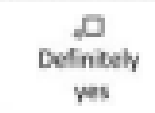 \\
\hline 22. Did you hime to pary for this honpital itar? & \multicolumn{4}{|c|}{ 口 Yes ${ }_{2}$ 口 No, skip 023} \\
\hline 23. Do you consider this hospinal stay tos eapersine? & \multicolumn{4}{|c|}{ प्रes, एNo } \\
\hline 24. How would yoy rate your goveral hesith? & 口 Poor & ב Far & D Good & ¿ $\square$ txredlent \\
\hline $\begin{array}{l}\text { 25. What is the highest yase of level of schos that you have } \\
\text { completed? }\end{array}$ & \multicolumn{4}{|c|}{ 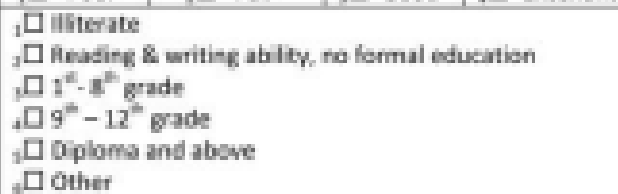 } \\
\hline
\end{tabular}

Permission to use this tool I-PAHC survey for the project was granted by the author, Dr.

Bradley, on May 28, 2020. 